\title{
Participation in setting technology standards and the implied cost of equity
}

\author{
Xin Deng ${ }^{\text {a }}$, Qian Cher Li ${ }^{\text {b,* }}$, Simona Mateut ${ }^{\text {b }}$ \\ ${ }^{a}$ Alliance Manchester Business School, UK \\ ${ }^{\mathrm{b}}$ Nottingham University Business School, UK
}

\section{A R T I C L E I N F O}

\section{Keywords:}

Cost of equity

Uncertainty

Technology standards

Standard setting organizations (SSOs)

\begin{abstract}
A B S T R A C T
This study empirically investigates the financial market's reaction to firms' participation in standard setting organizations (SSOs) in terms of firms' implied cost of equity capital - the discount rate applied by investors to a firm's expected future cash flows. Our analysis utilizes a panel of 3350 US public firms and their membership of 183 SSOs operating in a range of technology domains between 1996 and 2014. It shows a significantly lower cost of equity for SSO participants. We then empirically document a causal link between SSO membership and a firm's cost of equity, by exploiting exogenous variations in membership count linked to SSO closures and an instrumental variable measuring SSO availability. Our results underscore the important role of SSO membership in mitigating the perceived riskiness of a firm, particularly when it faces high degrees of technological uncertainty, product-market uncertainty, and information asymmetry.
\end{abstract}

\section{Introduction}

Business involvement in the development of technology standards (e. g., 5G mobile, Wi-Fi and internet standards) that is coordinated by standard setting organizations (SSOs) has received increasing attention from corporate managers and policymakers alike. The voluntary consensus-based standards that typically emerge from this process relate to minimum quality, health and safety, variety reduction, interoperability and so forth. Media coverage of standardization has also expanded. For instance, when AT\&T and seven other companies joined the Telecommunications Industry Association (TIA) in 2015, a suite of benefits were reported in the media, ranging from better industry intelligence to improved network opportunities. At the same time, publicly traded US firms frequently disclose information relating to their participation in standard setting in their financial reports, to provide crucial business information to investors. ${ }^{1}$

Notably, scholarly attention to the economic and strategic implications of firm engagement in standardization has steadily increased. Focussing on business startups in the networking/data communications industries, Waguespack and Fleming (2009) find that participants in the Internet Engineering Task Force (IETF) open-technology community, which develops standards for the Internet, have a higher likelihood of an initial public offering or acquisition. Moreover, Aggarwal et al. (2011) show that a larger number of firms engaging in a standard-setting initiative in information technologies decreases the market risk of individual participants, but concomitantly increases their idiosyncratic risk. While these studies provide useful insights for a narrow set of industries and specific technologies, how the capital markets respond to wider business participation in the many SSOs remains a crucial but unresolved question. Our study addresses this knowledge gap by using comprehensive firm-level data from a broad set of industries involved in technology standardization to link firms' cost of equity with their participation in SSOs across a diverse range of technology domains.

To unravel how participation in standard development can influence a firm's cost of equity is of great importance for its long-term investment and financing decisions. The cost of equity capital is the discount rate that the market applies to a firm's expected future cash flows to determine its current market value (Shleifer and Vishny, 2003; Boubakri et al., 2012). We develop an analytical framework to postulate that participation in technology standardization may reduce a firm's riskiness as perceived by the capital markets. As a result, the firm will be rewarded with a lower cost of equity and an attendant improvement in its overall economic performance. First, SSO participation can reduce a firm's risk of failure in its $R \& D$ investment through the knowledge

\footnotetext{
* Corresponding author.

E-mail address: cher.li@nottingham.ac.uk (Q.C. Li).

1 For instance, ACI Worldwide Inc., a large technology company that provides payment systems, disclosed in its 2018 10-K report its membership of several SSOs,

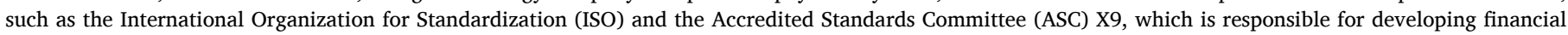
service standards. The Online Appendix A presents excerpts from such 10-K reports and examples of media reports.
} 
exchange with other SSO members and alignment of its innovation effort with the likely technology developments within the industry (thereby reducing technological uncertainty). Second, SSO membership, at the same time, mitigates uncertainty in the firm's products demand by opening new markets, setting anticipatory standards and avoiding standards battle in the market (thereby reducing product-market uncertainty). Third, most innovative firms are dependent on external finance and affected by information asymmetry problems (Acharya and $\mathrm{Xu}, 2017$ ). Investors often have difficulties in distinguishing good $\mathrm{R} \& \mathrm{D}$ projects from bad ones due to asymmetric information (Hall, 2010). Being an SSO member can therefore send a positive signal to investors about a firm's value and improve transparency, all of which can attenuate the information failures a firm may suffer in the capital markets and maintain its investor recognition.

Our empirical analysis utilizes a panel of 3350 US listed firms covering the period 1996-2014. Information on firm-level affiliations with 183 SSOs spanning a range of technology domains is drawn from the Searle Center Database on Technology Standards and Standard Setting Organizations (Baron and Spulber, 2018). We find robust evidence that membership of SSOs plays a significant role in lowering a member firm's implied cost of equity. Most notably, a firm's first SSO membership is associated with a strong reduction in its cost of equity. In line with our conceptual framework, our ensuing analysis reveals that the relationship between a firm's SSO membership and its cost of equity is conditional on several factors, including business risks stemming from technological uncertainty and/or product-market uncertainty as well as information asymmetry in the financial market. More specifically, utilizing a number of empirical measures to unpack these channels for risk mitigation, we find that SSO members operating in environments that are characterized by higher levels of technological uncertainty, product-market uncertainty and/or asymmetric information benefit from a sizable reduction in their cost of equity.

We exploit two types of exogenous variations in SSO membership to address the endogeneity concerns in our study. We first utilize the variation in a firm's exposure to SSO availability in relevant industries to construct our instrumental variable (IV), which is plausibly linked to a firm's membership decision but uncorrelated with the error term in the model used to determine the implied cost of equity. This IV analysis corroborates our observed negative correlation between SSO membership and a firm's cost of equity. Our second identification strategy relies on the difference-in-differences (DiD) method. In this setting, the closures of eight SSOs represent an external (supply-side) shock that in some instances directly affects a firm's membership count but is unrelated to business activities, including firm-specific standardization strategies. Our DiD results establish that the exogenous reductions in firms' membership count caused by SSO closures have a causal effect on their cost of equity.

Our final extension of the analysis examines to what extent the relationship between a firm's SSO membership and its cost of equity is contingent on which SSOs it chooses to join, as well as its patenting characteristics. First, we consider whether investors perceive risk differently in firms that are members of more influential SSOs. To do so, we utilize network analysis to derive a centrality-based measure of SSO influence within the standardization network and show that, in comparison with members of more peripheral SSOs, firms participating in influential SSOs have a lower cost of equity. Second, taking into account firm-level heterogeneity, we interact a firm's membership decision with the strength of its patent portfolio in terms of patent applications and ownership of standard-essential patents (SEPs). We find that patentingintensive firms and particularly SEP holders that participate in standard development are associated with a lower cost of equity.

Our study makes several empirical contributions. First of all, to the best of our knowledge, we present the first comprehensive analysis of the relationship between SSO membership and firms' cost of equity capital by utilizing robust evidence from a large sample of firms as well as an extensive range of SSOs that operate across diverse technology domains. Our novel evidence highlights that SSO participation can have a causal impact on a firm's cost of equity financing. Robust evidence surrounding this relationship holds the key to a better understanding of the innovation financing issues in some of the most dynamic and important industries of the economy. Second, our study contributes to the burgeoning literature on the economic and strategic implications of business organizations' involvement in standardization (e.g., Simcoe et al., 2009; Waguespack and Fleming, 2009; Aggarwal et al., 2011). We focus on the financial impact and document that the capital markets respond positively to a firm's participation in SSOs. We empirically unpack three channels through which SSO might affect the cost of equity: reductions in uncertainty stemming from both technological innovation and the product market; and the signalling effect of SSO participation mitigating information asymmetry. Finally, our paper contributes to the stream of the literature focusing on innovation- and technology-related factors that affect a firm's cost of equity. Lui et al. (2016), for instance, find that US listed firms which adopted (disruptive) innovations in information technology are associated with a lower cost of equity. Our paper reveals that a firm's cost of equity capital can also be reduced through collaborative innovation, in the form of participation in the collective development of open technology standards.

The remainder of the paper is organized as follows. Section 2 presents our analytical framework, building on related studies in the literature. Section 3 describes the data and Section 4 introduces our econometric models. Section 5 presents our identification strategy and estimation results. We present extended analysis in Section 6 before concluding in the last section.

\section{Analytical framework}

Early studies on firms' engagement in standardization link competition strategies to market externalities (Besen and Farrell, 1994; Katz and Shapiro, 1994). Firms choose their standardization strategies in accordance with certain properties of the market and competition (Blind et al., 2017). Compatibility standards avoid winner-takes-all market competition and give firms access to new markets (David and Steinmueller, 1994; Soh, 2010), while anticipatory standards enable the creation of new markets (Blind and Mangelsdorf, 2016). Recent years have witnessed growing standard development for emerging complex technical systems where SSOs often arise to influence expectations, facilitate coordination and achieve compatibility. SSO participants further benefit from state-of-the-art technology, knowledge exchange and early indication of future technologies. ${ }^{2}$

Not all firms, however, partake in standardization, nor is it always feasible for a firm to join all pertinent SSOs in the domains where it operates. ${ }^{3}$ Selective participation can be explained by sizable pecuniary costs (meeting attendance and membership can cost $\$ 10,000-\$ 60,000$, depending on the tier of membership and business size) as well as nonpecuniary costs (human resources, particularly technical personnel, as well as R\&D investment to develop technical contributions to a proposed standard) (Updegrove, 2006; Baron and Spulber, 2018). Additional barriers to joining SSOs include unintended leakage of proprietary knowledge, unwanted obligations of members around the disclosure of potential SEPs and the FRAND ${ }^{4}$ licensing commitments entered into by SEP holders (Delcamp and Leiponen, 2014; Baron et al., 2019).

\subsection{SSO participation and the cost of equity}

Technology standards (e.g., web standards and telecommunication

\footnotetext{
${ }^{2}$ Shorter lead times can give SSO members a competitive advantage in developing their standard-compliant technologies and new products (Baron et al., 2019).

${ }^{3}$ We thank the editor and a reviewer for suggesting this point.

4 This stands for 'fair, reasonable and non-discriminatory' licensing terms.
} 
standards) encompass an industry's technological base and offer a nonproprietary (public) technical infrastructure upon which modular parts can be integrated to build more complex system-level technologies and products. Participation in developing these standards can thus allow firms to exploit early the "infratechnology" embodied in them, which will in turn reduce business risks at all stages of a firm's innovation process from initial R\&D to technology commercialization (Tassey, 2000; Foucart and Li, 2021). We outline below three main channels whereby being a SSO member can affect the capital market perception of a firm's riskiness: technological uncertainty, product-market uncertainty and information asymmetry.

Technological uncertainty. The primary role of SSOs is to coordinate R\&D and innovation around common technological paradigms to achieve compatibility and interoperability of the technologies concerned. SSO participation can considerably alleviate the risks associated with innovation by levelling the playing field and enabling learning through spillovers (Waguespack and Fleming, 2009; Delcamp and Leiponen, 2014; Blind et al., 2017). Rysman and Simcoe (2008) show that SSOs facilitate the emergence and diffusion of higher-quality technologies. Using data for UK manufacturing firms, Foucart and Li (2021) also find empirical support for their theoretical prediction that technology standards can be used by firms (especially those further away from the technological frontier) to hedge the risky process of developing innovative products. Engagement in standard setting early on can thus particularly reduce the uncertainty associated with the adoption of non-standardized technical specifications, investment in technical elements that become incompatible with future uniform standards, and general $R \& D$ failure in complex technologies. In addition to aligning business investment decisions with likely future technological developments, SSO member firms can seek to influence standards toward their preferred specifications (Blind and Mangelsdorf, 2016). Lastly, member firms can reduce their R\&D risks by contributing their technologies to standards under development, which will make the likelihood of subsequent endorsement of those technologies by SSOs significantly greater, thus bolstering the value of those technologies (Rysman and Simcoe, 2008; Waguespack and Fleming, 2009).

Product-market uncertainty. Involvement in standard development can also mitigate firm product-market uncertainty, in the form of market-demand uncertainty, competition, customer-base shocks and unpredictable consumer behaviors (e.g., Jalonen, 2012; Blind et al., 2017). Simcoe (2012) argues that coordinated standard setting circumvents the uncertainty, duplication and intense competition of a standards war. The increased compatibility and interoperability resulting from standard development can especially facilitate the path to a larger consumer market across economic sectors (David and Steinmueller, 1994). Early exposure to (proposed) standards allows firms developing new technologies to benefit from scale and scope economies, as well as efficiency gains (David and Steinmueller, 1994; Blind and Mangelsdorf, 2016).

In light of the above discussion, we posit that capital market participants are likely to associate SSO members with lower technological uncertainty, which in turn will render the cost of equity lower. Furthermore, we would expect stronger effects of SSO participation on the cost of equity capital in industries with high product-market uncertainty. There is, in addition, another factor that might reduce the cost of equity for firms that are members of SSOs, and that relates to the information asymmetry that characterizes the general operation of the capital markets. Accordingly, we turn our attention to the positive signalling effect of SSO participation on a firm's perceived riskiness.

Information asymmetry. Investors may not easily observe the quality of research projects and technologies owned by innovative firms. Firms may also strategically withhold information on their projects and technologies either to fund risky $R \& D$ projects at the expense of investor profits (the agency problem) or to shield information on their technologies from their competitors. Membership of a SSO can reduce the information asymmetry by signalling to investors the quality of the firms' projects and technologies. SSO participation indicates the firm's ability to directly benefit from both knowledge spillovers within the SSO networks and early access to emerging standards. Investors can also expect SSO member firms to scan the environment for crucial information on technologies, hiring, rival firms and markets, as well as to influence standards without significant resource investment (Waguespack and Fleming, 2009). The disclosure of SSO membership (i.e., active involvement in the development of standards) will also plausibly increase transparency in both operations and investments (David and Steinmueller, 1994). Therefore, we would expect stronger effects of SSO participation on the cost of equity capital of firms with high information asymmetry. Our ensuing empirical analyzes test the operation of these three mechanisms.

\section{Data and methods}

\subsection{Sample construction}

We utilize several data sources to construct our main sample. We start by drawing accounting data from the Compustat-CRSP Merged Database covering all US listed firms. Then, we name-match all firms with information collected from the Searle Center Database (SCDB) to identify if they are members of any SSOs over the period 1996-2014. The SCDB offers the most comprehensive and systematic data on the membership of 191 SSOs that develop and/or promote technology standards in a range of technology domains (for a detailed description of the SCDB, see Baron and Spulber, 2018). For all matches, we manually check firm names and postcode information on the Internet. We are able to match our US public firms to 183 SSOs in the SCDB. Since the SCDB covers most technology standardization, we consider the unmatched Compustat firms in our sample as non-members of SSOs in a given year. We collect stock prices, returns, as well as the year of firms' initial public offering or trading from the CRSP database. Patent data is obtained from Orbis Intellectual Property (Orbis IP).

Firm participation in SSOs developing or promoting technology standards is prevalent in, but not limited to, information and communication technology (ICT) industries. To ensure our research questions are meaningfully tested, we carefully choose the industry composition of our sample. We consider as relevant all (2-digit SIC) industries (excluding the financial and the public sectors) in which at least $10 \%$ of firms are recorded in the SCDB over 1996-2014. ${ }^{5}$ Table 1 lists the 14 industries selected. Note that all industries identified by Brown et al. (2009) as high-tech sectors (SIC codes 28, 35, 36, 37, 38 and 73) are listed. While these sectors are the largest joint contributor (over $80 \%$ ), other industries account for the remaining sizable proportion of our sample. ${ }^{6}$ Fig. 1 shows the number of SSOs that are actively developing standards in each of the 20 technology domains in which our sample of firms operates; many SSOs operate in multiple domains. ${ }^{7}$ The domains with the largest numbers of active SSOs are software, wireless and mobile, hardware, network and information technology.

\footnotetext{
${ }^{5}$ While Chemicals and Allied Products (SIC 28) narrowly misses the $10 \%$ cutoff, it has the highest R\&D intensity among all the industries. Moreover, it includes the biotechnology sector, which, as Acharya and Xu (2017) indicate, relies heavily on external capital. It is therefore of great interest to study the relationship between SSO participation and the cost of equity in this industry. Our results remain unaffected if we exclude it from our sample.

${ }^{6}$ In robustness checks, we restrict our sample to ICT industries. Table OB1 in the Online Appendix B reports the estimates obtained from this smaller sample. The results are similar but stronger.

7 Similar to Baron and Spulber (2018), we start by searching the Internet archive of standards consortia provided by Andy Updegrove (https://www. consortiuminfo.org) for classification of SSOs in 2014, the last year of our sample. For the few SSOs in our dataset not listed on Consortiuminfo.org, we search their websites to identify the areas they are working on and manually assign them to relevant technology domains.
} 
Table 1

Industry composition of the sample.

\begin{tabular}{lll}
\hline SIC code & Description & Observations \\
\hline 22 & Textile Mill Products & 261 \\
23 & Apparel and Other Textile Products & 584 \\
26 & Paper and Allied Products & 574 \\
27 & Printing and Publishing & 641 \\
28 & Chemicals and Allied Products & 5879 \\
35 & Industrial Machinery and Equipment & 3605 \\
36 & Electronic and Other Electric Equipment & 5006 \\
37 & Transportation Equipment & 1424 \\
38 & Instruments and Related Products & 4085 \\
39 & Miscellaneous Manufacturing Industries & 564 \\
48 & Communications & 1625 \\
53 & General Merchandise Stores & 405 \\
73 & Business Services & 7043 \\
87 & Engineering and Management Services & 1128 \\
Total & & 32,824 \\
\hline
\end{tabular}

Detailed descriptions of the four models and the Hou et al. (2012) procedure are provided in the Appendix. ${ }^{8}$

We follow Hail and Leuz (2009) and construct our implied cost of equity measure (ICE) as the equal-weighted average of the four individual estimates. This approach has the additional benefit of mitigating the effects of measurement errors associated with any particular model (Dhaliwal et al., 2016). To maximize coverage, we require a firm to have at least one non-missing individual estimate to calculate our composite measure (Hou et al., 2012). Our results remain qualitatively unchanged when we require all four individual estimates to be non-missing, but the sample size drops considerably.

\subsection{Empirical model}

We analyze the effect of SSO membership on the implied cost of equity by estimating the following baseline model:

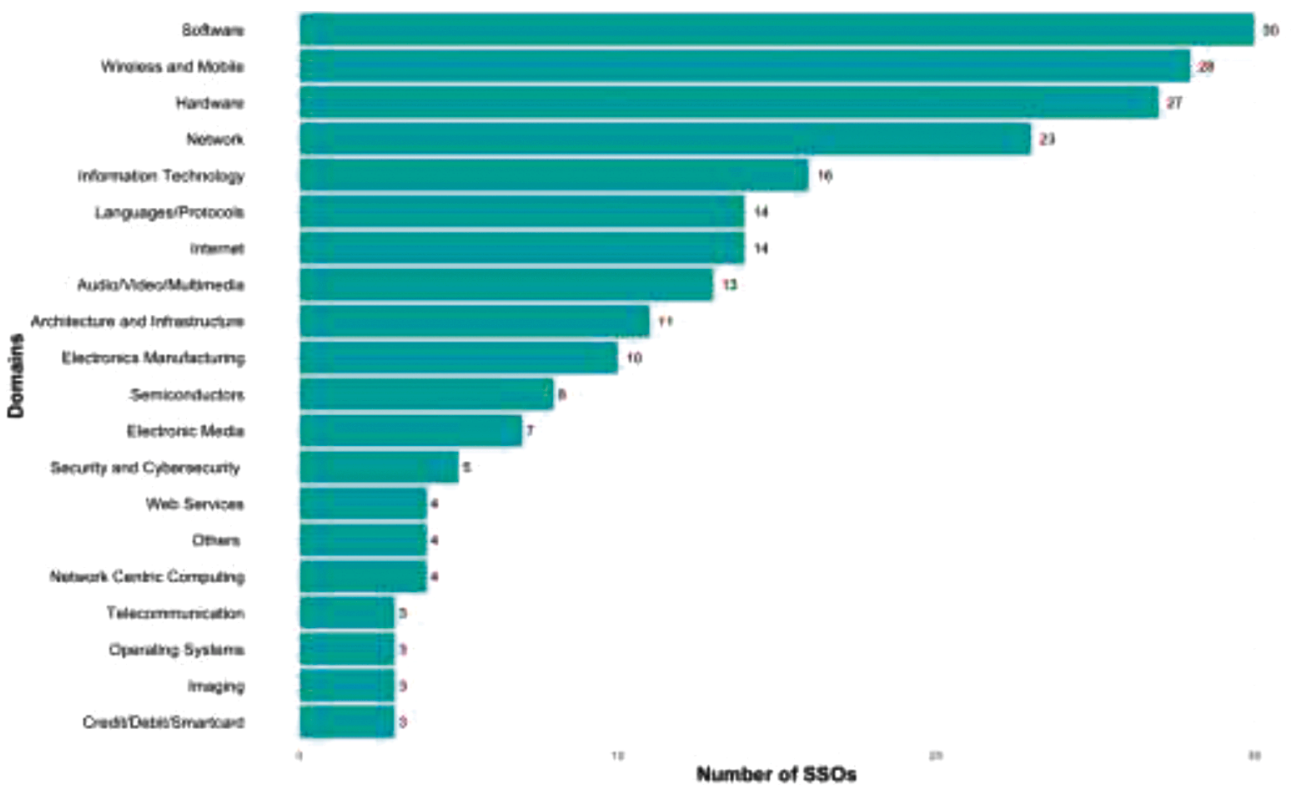

Fig. 1. Number of SSOs and technology domains in 2014 (note that SSOs may operate in multiple domains)

\subsection{Implied cost of equity}

We empirically estimate the cost of equity implied by the firms' current market value and their future cash flows. This approach does not rely on noisy realized returns or on specific asset pricing models. Following recent studies (e.g., Hail and Leuz, 2009; Boubakri et al., 2012; Ortiz-Molina and Phillips, 2014; Dhaliwal et al., 2016; Pham, 2019), we construct our implied cost of equity measure based on four models: two residual income valuation models (Gebhardt et al., 2001; Claus and Thomas, 2001), a modified price-earnings growth model (Easton, 2004) and an abnormal earnings growth valuation model (Ohlson and Juettner-Nauroth, 2005). A common caveat of the four models concerns their use of analysts' forecasts. First, analyst-based implied cost of equity is not a reliable proxy for expected returns and has little predictive power for future realized returns (Hou et al., 2012). Second, analyst forecasts are available only for a subset of firms, often underrepresenting small and financially distressed firms. Third, firms with analyst data also suffer from the lack of earnings forecasts beyond the second year. To address these issues, following Pham (2019), we use the forecasting procedure developed by Hou et al. (2012) to derive earnings forecasts. More specifically, to calculate the individual estimates in the four models we use the earnings forecasts obtained from the cross-sectional profitability model in Fama and French (2000, 2006).
$I C E_{i, t}=\alpha_{i}+\beta M E M B E R_{i, t-1}+\gamma$ Controls $_{i, t-1}+v_{j}+\mu_{t}+\epsilon_{i, t}$

where $I C E_{i, t}$ is the "composite" implied cost of equity measure calculated for firm $i$ in year $t$. MEMBER $R_{i, t-1}$ is a binary variable that takes the value 1 if firm $i$ is a member of any SSO in year $t-1$, and 0 otherwise. As usual, $\in_{i, t}$ is the error term, while $\alpha_{i}, v_{j}$, and $\mu_{t}$ are firm-, industry- and timespecific effects, respectively.

Our study uses firms' SSO memberships as recorded in the SCDB to capture their participation in technology standardization. The SCDB provides lists of all firms designated as members of SSOs that develop and/or promote technology standards. Excluding observers, these lists include all voting members and all levels of membership providing some influence over standard development (Baron and Spulber, 2018). In the extended analysis section, we attempt to account for heterogeneity in the mode and extent of involvement of individual members in standard development.

In line with previous studies (e.g., Hail and Leuz, 2009; Boubakri et al., 2012; Fu et al., 2012; Ortiz-Molina and Phillips, 2014; Pham,

\footnotetext{
${ }^{8}$ The Online Appendix B provides detailed explanations and results obtained with two ex-ante cost of equity measures employed in earlier studies.
} 
2019), Controls $s_{i, t-1}$ is a set of variables known to influence the cost of equity: the market-to-book ratio (MTB); the leverage ratio (LEVERAGE), calculated as the ratio of long-term debt to total assets; the return on assets (ROA); firm size (SIZE), calculated as total real assets (using 2010 as reference) ${ }^{9}$ and the annual standard deviation of monthly stock returns (VOLATILITY). AGE is the number of years since the firm's initial public offering or first trading. Natural logarithms of MTB, SIZE, VOLATILITY and AGE are used. The forecast errors (FORECASTER) are calculated as earnings forecasts next year minus actual earnings, scaled by lagged total assets.

Importantly, we control for firm innovation (PATAPP), measured as the annual number of patent applications (eventually granted). Patents are reported to have a role in signalling the quality of a firm's $R \& D$ projects and thus mitigating the effect of uncertainty and information asymmetry on investors' perceived risk of unsuccessful research outcomes (Griliches, 1990; Hall et al., 2005; Czarnitzki and Toole, 2011; Hussinger and Pacher, 2019). As we control for patenting activity, the $\beta$ coefficient on MEMBER should capture any additional informational effects of participating in SSOs on the firm's cost of equity. To check the robustness of our results, we measure firms' innovation with their patent stock and forward citations, alternatively. These estimates are presented in the Online Appendix, Table OB1. ${ }^{10}$

\subsection{Descriptive statistics}

Our final sample used in the estimations contains 32,824 firm-year observations for 3350 listed US firms spanning the period 1996-2014. We eliminate firms with fewer than three consecutive annual observations and winsorize the $1 \%$ tails of all continuous firm-level variables.

Table 2 presents a summary of the variables used in the empirical analysis. The mean value of the cost of equity in our sample is around $13.5 \%$, similar to that reported in Hou et al. (2012). On average, 16.1\% of the observations refer to SSO member firms and the average number of memberships is around 0.6 in our sample. ${ }^{11}$ Of the 3350 firms in our sample, 909 participate in at least one SSO. There is major variation in membership patterns among participants, with 448 firms participating in more than one SSO (the largest number is 60). Simple t-test results ( $t$ $=15.470$ ) confirm that the average implied cost of equity is 3.04 basis points lower for SSO members than for non-members.

The breakdown of the summary statistics by industry (Panel B) reveals that the average implied cost of equity ranges from $9.9 \%$ in General Merchandise Stores (SIC 53) to as high as $15.2 \%$ in Textile Mill Products (SIC 22). As expected, the highest SSO participation rate (29.7\%) is in Electronic and Other Electric Equipment (SIC 36), which is nearly twice as high as the average participation rate for the whole sample. The average SSO membership count (1.289) is also the highest in this industry.

The pairwise correlation coefficients presented in Panel C are small in magnitude and generally statistically significant at 5\% level. Members of SSOs are associated with a lower implied cost of equity. The signs of the other coefficients are consistent with previous studies: the implied cost of equity is negatively related to firm size, the market-to-book ratio,

\footnotetext{
${ }^{9}$ If market capitalization (i.e., the average market equity value at the beginning and end of calendar year $t-1$ ) is used instead for firm size, the results are unaffected.

${ }^{10}$ In a separate exercise, we use the CRSP-linked granted patents data constructed by Kogan et al. (2017) made available at https://iu.app.box.co m/patents. Following Guo et al. (2019), we exclude observations after 2006 to mitigate the truncation problem arising from the time gap between application and grant dates. Our results remain unaffected when we use the much shorter panel.

${ }^{11}$ We carefully inspect membership data accuracy. For instance, we ascertain that no firms are assigned membership of an SSO in the years following its closure. See Section 5.2 Difference-in-Differences (DiD).
}

returns on assets and age, while being positively associated with stock return volatility and forecast errors.

\section{Estimation results}

\subsection{Baseline models}

Table 3 presents our fixed effects estimates of Eq. (1), controlling for firm- and time-specific effects. Standard errors are clustered at the firm level and the corresponding t-statistics are reported in parentheses. In column (2) we control for time-invariant industry-specific effects using the Hausman-Taylor estimator. In column (3) we employ the fixed effects estimator on Eq. (1), augmented with industry-time interaction terms. As expected, SSO participation is associated with a lower cost of equity. Overall, we find a significantly negative estimated parameter of $M E M B E R$; it indicates that the cost of equity is 0.6 basis points lower for SSO member firms. Firms with a larger number of patent applications also have a lower cost of equity. This result is in line with previous evidence that patenting has a positive effect on firms' market value, by allowing firms to better appropriate economic rents from their invention and offering them IP protection to fend off competition (Hall et al., 2005; Belenzon and Patacconi, 2013).

Turning to the other control variables, we find that they exhibit the expected signs. Consistent with Boubakri et al. (2012), Fu et al. (2012), Chen et al. (2016) and Pham (2019), the market-to-book ratio (MTB) is negatively related to the implied cost of equity. A higher volatility in returns (VOLATILITY) is associated with a larger implied cost of equity, as documented in Hail and Leuz (2009), Boubakri et al. (2012) and Boubaker et al. (2018). The positive association between leverage (LEVERAGE) and the implied cost of equity is consistent with Boubakri et al. (2012), Chen et al. (2016) and Boubaker et al. (2018). Larger and more profitable firms are able to raise external capital at a lower cost (Boubakri et al., 2012; Pham, 2019). Consistent with Boubakri et al. (2012), firm age (AGE) positively relates to the implied cost of equity. Finally, a larger forecast error (FORECASTER) correlates positively with the implied cost of equity (Hail and Leuz, 2009).

In columns (4), (5) and (6), we exploit time-varying membership information and use alternative measures of SSO participation. We first exclude firms with permanent SSO membership throughout our sample period and concentrate on those firms for which we observe membership variation over time (column (4)). Next, we disregard firms that never participate and focus on the first recorded SSO participation (fMEM$B E R$ ). In column (6), we tally the number of SSO memberships held by a firm each year (MEMBERCOUNT). The estimates presented in columns (4) to (6) indicate a consistently negative and statistically significant correlation between each measure of SSO participation and firms' implied cost of equity. Most notably, a firm's first-recorded participation in an SSO (i.e., first entry) is associated with a large reduction in its cost of equity.

\subsection{Mechanisms}

Our baseline models have consistently pointed to a significant negative association between participation in SSOs and a firm's cost of equity. If being an SSO member improves investors' perceptions of the firm's riskiness, we should see the benefits of SSO participation being concentrated in member firms that have higher exposure to risks. In line with our analytical framework set out earlier, we focus on risks arising from technological and product-market uncertainty, as well as information asymmetry in the capital market. More specifically, we expect that the capital market reacts more strongly to firms joining SSOs if they are more exposed to uncertainty in technological innovation, uncertainty in product-market conditions, and are faced with high information asymmetry. We consider each dimension separately below. 
Table 2

Descriptive statistics.

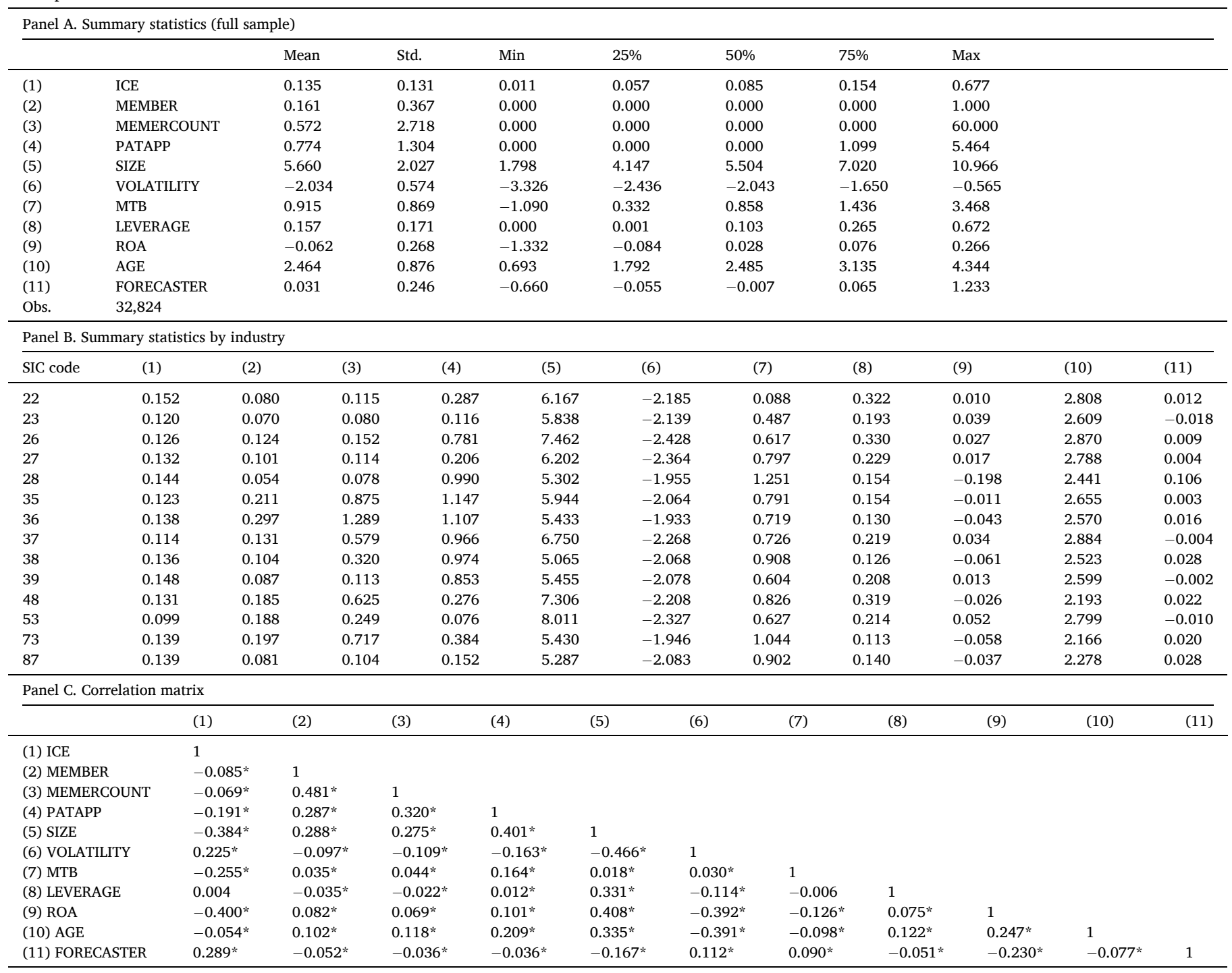

Refer to Table 1 for detailed industry description.

$* p<0.05$.

\subsubsection{Technological uncertainty}

We first explore to what extent the relationship between SSO participation and the cost of equity is contingent on technological uncertainty associated with R\&D investment. In line with our analytical framework, we conjecture that R\&D-intensive firms encounter greater uncertainty, such as R\&D investment failure, unexpectedly surging costs in innovation and technical incompatibility (Czarnitzki and Toole, 2011). We use firm-level R\&D intensity (R\&D expenses over total sales) to proxy for such technological uncertainty. ${ }^{12}$ We then create two dummies High (Low) RDI equal to 1 if the firm's R\&D intensity is above (below) the industry-median in a given year, and 0 otherwise. ${ }^{13}$

The results presented in column (1) of Table 4 suggest that R\&Dintensive SSO members have a reduced cost of equity, in line with our conjecture that participation in SSOs helps firms overcome uncertainty stemming from risky $\mathrm{R} \& \mathrm{D}$, as these firms are able to learn through

\footnotetext{
$\overline{12}$ Replacing missing values for $\mathrm{R} \& \mathrm{D}$ expenses with 0 is inconsequential for our results.

${ }^{13}$ We compute every industry-year median in this section at the 3-digit SIC level.
}

technology spillovers and better able to align their R\&D investment with future technological developments.

\subsubsection{Product-market uncertainty}

Our conceptual framework also underlines that the capital market's perceptions of the riskiness of SSO members may be conditional on the uncertainty these firms face in the product market. A firm's productmarket uncertainty is primarily determined by the volatility in the aggregate market demand. For a given level of volatility in aggregate market demand, a firm's product-market uncertainty can also derive from sources such as the intensity of competition it faces in the market and any specific shocks that might hit its customer base. We thus employ three empirical proxies to capture a firm's risk exposure in its product market.

Above all, following Czarnitzki and Toole (2011) and Garcia-Vega et al. (2021), we compute a measure of product-market uncertainty at the firm level as follows: 
Table 3

Baseline results.

\begin{tabular}{|c|c|c|c|c|c|c|}
\hline & (1) & (2) & (3) & $\begin{array}{l}\text { (4) } \\
\text { Non-permanent member }\end{array}$ & $\begin{array}{l}\text { (5) } \\
\text { First entry }\end{array}$ & $\begin{array}{l}\text { (6) } \\
\text { MEMBER COUNT }\end{array}$ \\
\hline MEMBER & $\begin{array}{l}-0.007^{* * *} \\
(-3.012)\end{array}$ & $\begin{array}{l}-0.007 * * * \\
(-2.989)\end{array}$ & $\begin{array}{l}-0.006^{* * *} \\
(-2.670)\end{array}$ & $\begin{array}{l}-0.007 * * * \\
(-2.859)\end{array}$ & & \\
\hline fMEMBER & & & & & $\begin{array}{l}-0.013^{* * *} \\
(-3.326)\end{array}$ & \\
\hline MEMBERCOUNT & & & & & & $\begin{array}{l}-0.011 * * * \\
(-4.974)\end{array}$ \\
\hline PATAPP & $\begin{array}{l}-0.003^{* *} \\
(-2.395)\end{array}$ & $\begin{array}{l}-0.004^{* * *} \\
(-3.224)\end{array}$ & $\begin{array}{l}-0.003^{* *} \\
(-2.380)\end{array}$ & $\begin{array}{l}-0.003^{* * *} \\
(-2.689)\end{array}$ & $\begin{array}{l}-0.000 \\
(-0.183)\end{array}$ & $\begin{array}{l}-0.003 * * \\
(-2.327)\end{array}$ \\
\hline SIZE & $\begin{array}{l}-0.027 * * * \\
(-15.722)\end{array}$ & $\begin{array}{l}-0.029 * * * \\
(-16.820)\end{array}$ & $\begin{array}{l}-0.029 * * * \\
(-15.996)\end{array}$ & $\begin{array}{l}-0.029 * * * \\
(-15.712)\end{array}$ & $\begin{array}{l}-0.028^{* * *} \\
(-4.884)\end{array}$ & $\begin{array}{l}-0.028 * * * \\
(-15.879)\end{array}$ \\
\hline VOLATILITY & $\begin{array}{l}0.005^{* *} \\
(2.407)\end{array}$ & $\begin{array}{l}0.005^{* *} \\
(2.572)\end{array}$ & $\begin{array}{l}0.005^{* *} \\
(2.481)\end{array}$ & $\begin{array}{l}0.005^{* *} \\
(2.511)\end{array}$ & $\begin{array}{l}0.002 \\
(0.327)\end{array}$ & $\begin{array}{l}0.005^{* *} \\
(2.344)\end{array}$ \\
\hline MTB & $\begin{array}{l}-0.044^{* * *} \\
(-30.308)\end{array}$ & $\begin{array}{l}-0.044 * * * \\
(-30.645)\end{array}$ & $\begin{array}{l}-0.044^{* * *} \\
(-30.180)\end{array}$ & $\begin{array}{l}-0.045^{* * *} \\
(-30.139)\end{array}$ & $\begin{array}{l}-0.028 * * * \\
(-6.797)\end{array}$ & $\begin{array}{l}-0.044 * * * \\
(-30.272)\end{array}$ \\
\hline LEVERAGE & $\begin{array}{l}0.085^{* * *} \\
(11.534)\end{array}$ & $\begin{array}{l}0.087^{* * *} \\
(11.843)\end{array}$ & $\begin{array}{l}0.088^{* * *} \\
(11.851)\end{array}$ & $\begin{array}{l}0.091 * * * \\
(11.857)\end{array}$ & $\begin{array}{l}0.058^{* * *} \\
(2.899)\end{array}$ & $\begin{array}{l}0.089 * * * \\
(11.888)\end{array}$ \\
\hline$R O A$ & $\begin{array}{l}-0.130^{* * *} \\
(-20.741)\end{array}$ & $\begin{array}{l}-0.131^{* * *} \\
(-20.817)\end{array}$ & $\begin{array}{l}-0.129 * * * \\
(-20.507)\end{array}$ & $\begin{array}{l}-0.130 * * * \\
(-20.371)\end{array}$ & $\begin{array}{l}-0.135^{* * *} \\
(-5.370)\end{array}$ & $\begin{array}{l}-0.129 * * * \\
(-20.579)\end{array}$ \\
\hline$A G E$ & $\begin{array}{l}0.027^{* * *} \\
(8.915)\end{array}$ & $\begin{array}{l}0.022^{* * *} \\
(9.463)\end{array}$ & $\begin{array}{l}0.027^{* * *} \\
(8.645)\end{array}$ & $\begin{array}{l}0.027^{* * *} \\
(8.334)\end{array}$ & $\begin{array}{l}0.027^{* * *} \\
(2.780)\end{array}$ & $\begin{array}{l}0.027^{* * *} \\
(8.580)\end{array}$ \\
\hline FORECASTER & $\begin{array}{l}0.086^{* * *} \\
(15.797)\end{array}$ & $\begin{array}{l}0.087^{* * *} \\
(15.933)\end{array}$ & $\begin{array}{l}0.085^{* * *} \\
(15.849)\end{array}$ & $\begin{array}{l}0.086^{* * *} \\
(15.774)\end{array}$ & $\begin{array}{l}0.115^{* * *} \\
(5.440)\end{array}$ & $\begin{array}{l}0.085^{* * *} \\
(15.863)\end{array}$ \\
\hline Constant & $\begin{array}{l}0.223^{* * *} \\
(21.190)\end{array}$ & $\begin{array}{l}0.261^{* * *} \\
(15.865)\end{array}$ & $\begin{array}{l}0.185^{* * *} \\
(7.405)\end{array}$ & $\begin{array}{l}0.183^{* * *} \\
(7.244)\end{array}$ & $\begin{array}{l}0.244^{* * *} \\
(6.276)\end{array}$ & $\begin{array}{l}0.184^{* * *} \\
(7.358)\end{array}$ \\
\hline Observations & 32,824 & 32,824 & 32,824 & 31,694 & 4,138 & 32,824 \\
\hline$N$ of firms & 3350 & 3350 & 3350 & 3221 & 780 & 3,350 \\
\hline R-squared & 0.264 & & 0.276 & 0.280 & 0.257 & 0.276 \\
\hline Industry FE & NO & YES & YES & YES & YES & YES \\
\hline Year FE & YES & YES & YES & YES & YES & YES \\
\hline Firm FE & YES & YES & YES & YES & YES & YES \\
\hline
\end{tabular}

This table presents the fixed effects estimated coefficients (t-statistics in parentheses). The dependent variable is the composite implied cost of equity (ICE), based on the earnings per share forecasts derived with the HVZ procedure. In column 2 we use the Hausman-Taylor estimator, which allows inclusion of time-invariant industry effects. Columns 3-6 include industry-time interaction terms in the within groups model. In columns 1-4, MEMBER takes the value 1 if the firm participates in at least one SSO in year $\mathrm{t}-1$, and 0 otherwise. In column 4 , the sample excludes firms that have always participated in an SSO. In column 5, fMEMBER takes the value 1 when the firm participates in an SSO for the first time during our sample period, and 0 otherwise. In column 6 , we replace the membership indicator with a membership count variable (MEMBERCOUNT). The control variables include: PATAPP, measured as the natural logarithm of 1 plus the number of patents applied for in year t; firm size (SIZE) as the natural logarithm of total real assets; the natural logarithm of the market-to-book ratio (MTB); the ratio of long-term debt to total assets (LEVERAGE); the return on assets (ROA); the natural logarithm of the annual standard deviation of the monthly stock returns (VOLATILITY); AGE as the logarithm of 1 plus the difference between the current year and the year of the firm's initial public offering or first trading; and forecast errors (FORECASTER) as earnings forecasts for the next year minus actual earnings, scaled by lagged total assets. All variables (except FORECASTER) are measured at time $\mathrm{t}-1 .{ }^{*} p<0.1 ;{ }^{* *} p<0.05 ;{ }^{* * *} p<0.01$.

$p m u_{i}=\frac{\sqrt{\frac{1}{T} \sum_{t=1}^{T}\left[S_{i t}-\left(\frac{1}{T} \sum_{t=1}^{T} S_{i t}\right)\right]^{2}}}{\frac{1}{T} \sum_{t=1}^{T} S_{i t}}$,

where $p m u_{i}$ is the coefficient of variation of a firm's sales per employee $\left(S_{i t}\right)$. We obtain a (time-varying) industry-level measure of uncertainty by averaging the firm-level measure across all firms in an industry. We create two dummies High (Low) Pmu equal to 1 if the firm is in an industry with above (below) the median level of uncertainty in year $t$, and 0 otherwise. The results reported in column (2) of Table 4 suggest that SSO members with higher product-market uncertainty are associated with a reduced cost of equity.

Product-market uncertainty can arise also from sources like competition and customer-base shocks (Blind et al., 2017). We measure industry competition as decreasing industry concentration, the latter gauged via the standard Herfindahl-Hirschman Index (HHI). Following Hou and Robinson (2006), for each year $t$, we use the average value of the $\mathrm{HHI}$ for the past three years, which helps alleviate potential data errors in our analysis. We construct two dummies High (Low) Comp equal to 1 if the industry $\mathrm{HHI}$ is below (above) the year median, and 0 otherwise.

Finally, in line with Dhaliwal et al. (2016), we expect that a more concentrated customer base increases a supplier's risk, which can result in a higher cost of equity. Depending on a major customer for a large percentage of sales presents the supplier with the risk of losing substantial cash flows should a negative shock hit that customer. We use information from the Compustat segment customer files to identify all customers that account for at least $10 \%$ of a supplier's revenue. We measure supplier $i$ 's customer concentration across its $K$ major customers in year $t$ as:

Customer $H_{i t}=\sum_{k=1}^{K}\left(\frac{\text { sales }_{i k t}}{\text { sales }_{i t}}\right)^{2}$,

where sales $_{i k t}$ is supplier $i$ 's sales to major customer $k$ and sales $_{i t}$ is supplier $i$ 's total sales in year $t .{ }^{14} \mathrm{~A}$ high Customer HHI value indicates supplier $i$ has a concentrated customer base. Similar to Dhaliwal et al. (2016), we set the index equal to 0 if a supplier does not have any major customers and equal to 1 if a supplier depends on a single customer. We generate two dummies High (Low) CustConce equal to 1 if the customer concentration index is above (below) the industry-year median, and 0 otherwise.

Columns (3) and (4) of Table 4 report the results distinguishing among SSO members according to the degree of concentration in their product market and in their customer base, respectively. These estimates

\footnotetext{
14 The SFAS 1997 regulations require suppliers to identify their major customers. Our results hold when we use instead the total share of the major customers or when the customer concentration index includes disclosed data for corporate customers accounting for less than $10 \%$ of the supplier's sales.
} 
Table 4

Possible mechanisms.

\begin{tabular}{|c|c|c|c|c|c|c|c|}
\hline & \multirow{2}{*}{$\begin{array}{l}\text { Technological } \\
\text { uncertainty }\end{array}$} & \multicolumn{3}{|c|}{ Product-market uncertainty } & \multicolumn{3}{|c|}{ Information asymmetry } \\
\hline & & $\begin{array}{l}\text { (2) } \\
\text { Market uncertainty }\end{array}$ & $\begin{array}{l}\text { (3) } \\
\text { Market competition }\end{array}$ & $\begin{array}{l}\text { (4) } \\
\text { Customer concentration }\end{array}$ & $\begin{array}{l}\text { (5) } \\
\text { Financial constraint }\end{array}$ & $\begin{array}{l}\text { (6) } \\
\text { Analyst coverage }\end{array}$ & $\begin{array}{l}\text { (7) } \\
\text { Illiquidity }\end{array}$ \\
\hline MEMBER \# High RDI & $\begin{array}{l}-0.009 * * * \\
(-2.939)\end{array}$ & & & & & & \\
\hline MEMBER \# Low RDI & $\begin{array}{l}-0.001 \\
(-0.297)\end{array}$ & & & & & & \\
\hline MEMBER \# High Pmu & & $\begin{array}{l}-0.009^{* * * *} \\
(-2.976)\end{array}$ & & & & & \\
\hline MEMBER \# Low Pmu & & $\begin{array}{l}-0.003 \\
(-0.973)\end{array}$ & & & & & \\
\hline MEMBER \# High Comp & & & $\begin{array}{l}-0.007^{* *} \\
(-2.454)\end{array}$ & & & & \\
\hline MEMBER \# Low Comp & & & $\begin{array}{l}-0.005 \\
(-1.580)\end{array}$ & & & & \\
\hline MEMBER \# High CustConce & & & & $\begin{array}{l}-0.008^{* *} \\
(-2.322)\end{array}$ & & & \\
\hline MEMBER \# Low CustConce & & & & $\begin{array}{l}-0.006^{* *} \\
(-2.128)\end{array}$ & & & \\
\hline MEMBER \# High FC & & & & & $\begin{array}{l}-0.010 \% * * \\
(-3.038)\end{array}$ & & \\
\hline MEMBER \# Low FC & & & & & $\begin{array}{l}-0.004 \\
(-1.449)\end{array}$ & & \\
\hline MEMBER \# High AC & & & & & & $\begin{array}{l}-0.003 \\
(-1.243)\end{array}$ & \\
\hline MEMBER \# Low AC & & & & & & $\begin{array}{l}-0.011^{* * *} \\
(-3.309)\end{array}$ & \\
\hline MEMBER \# High Illiquid & & & & & & & $\begin{array}{l}-0.010^{* * *} \\
(-3.544)\end{array}$ \\
\hline MEMBER \# Low Illiquid & & & & & & & $\begin{array}{l}-0.002 \\
(-0.877)\end{array}$ \\
\hline Constant & $\begin{array}{l}0.193^{* * *} \\
(10.077)\end{array}$ & $\begin{array}{l}0.190 * * * \\
(7.769)\end{array}$ & $\begin{array}{l}0.185^{* * *} \\
(7.400)\end{array}$ & $\begin{array}{l}0.185^{* * *} \\
(7.407)\end{array}$ & $\begin{array}{l}0.189^{* * * *} \\
(7.643)\end{array}$ & $\begin{array}{l}0.222^{* * *} \\
(19.971)\end{array}$ & $\begin{array}{l}0.186 * * * \\
(7.382)\end{array}$ \\
\hline Controls & YES & YES & YES & YES & YES & YES & YES \\
\hline Observations & 24,499 & 32,124 & 32,824 & 32,824 & 31,077 & 31,482 & 32,809 \\
\hline$N$ of firms & 2632 & 3319 & 3350 & 3350 & 3315 & 3238 & 3349 \\
\hline R-squared & 0.277 & 0.279 & 0.276 & 0.276 & 0.280 & 0.271 & 0.276 \\
\hline Industry FE & YES & YES & YES & YES & YES & YES & YES \\
\hline Year FE & YES & YES & YES & YES & YES & YES & YES \\
\hline Firm FE & YES & YES & YES & YES & YES & YES & YES \\
\hline
\end{tabular}

This table presents the fixed effects estimated coefficients (t-statistics in parentheses). The dependent variable is the composite ICE measure. High (Low) RDI takes value 1 if the firm's R\&D intensity, measured as R\&D expenses over sales, is above (below) the industry-year median, and 0 otherwise. Product market uncertainty is calculated as the coefficient of variation of a firm's sales per employee. Following Garcia-Vega et al. (2021), High (Low) Pmu is set to 1 if the firm is in an industry with above (below) the median level of uncertainty in year $\mathrm{t}$, and 0 otherwise. Market competition is gauged by the Herfindahl-Hirschman Index (HHI), calculated for each industry (at the 3-digit SIC level) in each year. Following Hou and Robinson (2006), for each year t, we use the average value of the HHI for the past three years. High (Low) Comp is set equal to 1 if the annual value is below (above) the year-median, and 0 otherwise. Customer concentration is measured for each supplier firm as the sum of the squared shares of its major corporate customers. High (Low) CustConce is set to 1 if the firm's customer concentration is above (below) the industry-year median, and 0 otherwise. Firm financial constraints are proxied by the Kaplan and Zingales index. High (Low) FC takes the value 1 if the firm's KZ index is above (below) the industry-year median, and 0 otherwise. Analyst coverage is measured as the number of analysts following. High (Low) AC equal to 1 if the analyst coverage in an industry is above (below) the median in year t, and 0 otherwise. We calculate illiquidity following Amihud (2002). High (Low) Illiquid is set to 1 if the illiquidity in an industry is above (below) the median in year $t$, and 0 otherwise. We compute each industry-year median at the 3-digit SIC level. All dummy variables are measured at time $\mathrm{t}-1$. Controls include all other firm-level characteristics in Table $3 .{ }^{*} p<0.1 ; * * p<0.05 ;{ }^{* * *} p<0.01$.

imply that SSO membership is associated with a reduced cost of equity for firms exposed to high product-market uncertainty.

\subsubsection{Asymmetric information}

Finally, we investigate whether the impact of SSO participation is conditional on the frictions in the capital markets that are imposed by information asymmetry between firms and investors. Since there is no direct measure for information asymmetry, we follow the accounting and finance literature to utilize three proxies, viz. financial constraints, analyst coverage, and illiquidity. First, financial constraints capture the difficulty firms experience in obtaining all necessary outside financing, which largely stems from their inability to convince external funders about their quality. We compute the KZ index suggested by Kaplan and Zingales $(1997)^{15}$ to measure financial constraints and create two dummies High (Low) FC equal to 1 if the firm's KZ index is above (below) the industry-year median, and 0 otherwise. Second, in line with Chen and Lin (2017), we assume that financial analysts have the incentives and abilities to produce and distribute firm-specific information to the

\footnotetext{
15 The KZ index is calculated as $-1.002^{*}$ cash flow $+0.283^{*}$ Tobin $\mathrm{Q}+$ $3.139 *$ leverage $-39.368 *$ dividend $-1.315 *$ cash holding. Higher index values
} indicate stronger financial constraints. 
market. A larger number of analysts covering a firm can produce and transmit more information (Hong et al., 2000) thus alleviating information asymmetry between the firm they cover and its investors. Using data from the Institutional Brokers' Estimate System (I/B/E/S), we construct two dummies High (Low) AC equal to 1 if analyst coverage in an industry is above (below) the median in year $t$, and 0 otherwise. Finally, we proxy information asymmetry using illiquidity in the stock market. Following Amihud (2002), we construct the annual illiquidity level in an industry as the daily ratio of absolute stock return to its dollar volume averaged over the year. We then create two dummies High (Low) Illiquid equal to 1 if the illiquidity in an industry is above (below) the median in year $t$, and 0 otherwise.

The estimates in columns (5) to (7) of Table 4 show that SSO member firms are associated with a statistically significant reduction in their cost of equity if they face higher levels of information asymmetry as reflected in more severe financial constraints, lower coverage by financial analysts, and higher stock-market illiquidity. These findings elucidate that SSO participation can send a positive signal to investors about the quality of the firm's technologies and help maintain investor recognition by reducing information failures.

\section{Identification strategy}

We have used linear regression analysis to establish robust correlation between SSO membership and the cost of equity. To the extent that a lower cost of equity may better equip firms with financial resources to participate in SSOs, our results may suffer from an endogeneity bias arising from reverse causality. Our analysis has dealt with this (albeit not perfectly) by including membership status at time $t-1$. Our identification strategy relies on a battery of fixed effects to control for unobserved but fixed omitted variables. One possible concern is that member and non-member firms are systematically different, implying that these firm-specific characteristics drive our results rather than their SSO membership. For instance, a firm may join SSOs only to signal its innovation performance to the capital markets. Alternatively, while the investors may be aware of the firm's successfully patented technologies, additional payoffs may arise from SSO participation should these patents be incorporated into future standards. In this section, we adopt two different identification strategies: we implement the probit instrumental variable model and exploit a plausibly exogenous variation in membership count caused by SSO closures to address the endogeneity concerns in our paper.

\subsection{Instrumental variables (2SLS)}

A prominent motive for participation in standardization is to access technological opportunities arising from the diffusion of a standard in an industry. We assume that a firm's participation decision is influenced by SSO presence and linked technological opportunities in an industry as the standards gain market acceptance. To establish causality of SSO membership, we instrument it with the variable SSO Availability, which reflects the time-varying technological opportunities (across different domains) that are available to a firm as well as the extent of standardization within an industry. We start by assigning an SSO the industry codes (at the 3-digit SIC level) of all its member firms in year $t$. SSO Availability is calculated as the number of SSOs relevant to the focal firm (i.e., with exposure to the focal firm's industry) in year $t$. It is reasonable to assume that our IV plays a role in a firm's membership decision but is uncorrelated with the error term in the function of its implied cost of equity. We use the lagged variable in logarithmic form.

To operationalize our IV analysis, we follow the three-stage probit2SLS procedure suggested by Angrist and Pischke (2008) and Adams et al. (2009) to deal with the binary nature of our endogenous variable (MEMBER). Specifically: (i) we first estimate a probit model of firms' SSO participation on our IV and other control variables; (ii) we use the predicted probability $\widehat{M E M B E R}$ as an instrument in the first-stage of the 2SLS procedure; (iii) we follow with the second-stage 2SLS regression for the implied cost of equity on the control variables and the fitted values from the first-stage 2SLS. The advantage of this approach to the pseudo-IV procedure is that it does not require the binary response model of the first stage to be correctly specified. ${ }^{16}$ Our results suggest a strong positive correlation between SSO Availability and SSO participation, given that greater availability of relevant SSOs increases the likelihood of firms' SSO participation. The final-stage 2SLS results confirm the negative relation between SSO participation and firms' implied cost of equity, as the -0.074 estimated coefficient on MEMBER is statistically significant at the $5 \%$ level. For brevity, we report these IV results in Table OC1 in the Online Appendix C.

\subsection{Difference-in-differences (DiD)}

Our main identification strategy exploits the exogenous source of variation in firms' SSO membership count due to SSO closures in a difference-in-differences setting. SSOs may close for a variety of reasons, such as their initial agreed goals and objectives being fulfilled, their activities and technical specifications being transferred to other standards organizations, or a failure to achieve widespread adoption of their standards (e.g., losing a standards race). ${ }^{17}$ Such process is often characterized by a complex interplay of technological, market, cultural and political factors alike. We can thus reasonably expect that the factors leading to the closure of SSOs are not driven by individual firms' standardization strategies, nor should they directly influence investors' perceptions of the riskiness of specific firms, hence their cost of equity.

Arguably, closures provide more reliable identification in firms' SSO membership count than does the emergence of new SSOs. ${ }^{18}$ SSO creations are more likely when the industry transitions from obsolete to new technology standards; the standardization strategies of the founding members of the new SSOs drive new technology opportunities which can be anticipated to affect these firms' risk profiles. ${ }^{19}$ It follows that SSO closures better respond to technology evolution and collective demand for standardization from heterogeneous firms across sectors and geographies, thus to some degree attenuating the correlation with characteristics of individual firms, including their standardization strategies. ${ }^{20}$

To perform our DiD analysis, based on information from Consortiuminfo.org and other Internet sources, we first identify eight SSO closures within our sample period (the year of closure is given in parentheses): Universal Wireless Communications Consortium/UWCC (2001), TV Anytime Forum (2005), FlexRay Consortium (2009), Liberty Alliance Project (2009), WiMedia Alliance (2010), OpenAjax Alliance

\footnotetext{
${ }^{16}$ In contrast, the pseudo-IV procedure, in which we directly regress the cost of equity on the predicted value of $M E M B E R$ and the other control variables, guarantees consistency only if the first stage is correctly specified.

17 For example, three competing SSOs - 3GPP, 3GPP2 and IEEE - worked on distinct systems as potential solutions for the fourth generation of broadband cellular network technology. The LTE system developed by 3GPP achieved widespread global adoption and hence 3GPP2 became dormant after 2013.

${ }^{18}$ We thank a reviewer for suggesting this point and highlighting the implied asymmetry between closures and creations of SSOs.

19 For instance, the European Telecommunications Standards Institute (ETSI) partnered with other standards organizations to set up the $3^{\text {rd }}$ Generation Partnership Project (3GPP) in 1998. New technical specifications had to be developed for faster $3 G$ cellular networks as the $2 G$ networks were overwhelmed. Therefore, the creation of the new 3GPP may be endogenously determined with the standardization strategies of its founding member firms (Leiponen, 2008).

20 Leiponen (2008) and Delcamp and Leiponen (2014) use mergers across SSOs for identification, which offers exogenous sources of variation that are analogous to our setting. Due to the limited number of merger events during our sample period, we are unable to isolate the effect of SSO mergers on firms' membership count.
} 
(2013), International Imaging Industry Association/I3A (2013) and $3^{\text {rd }}$ Generation Partnership Project 2/3GPP2 (2013). ${ }^{21}$ As the effect of SSO closure in year $t$ on firms' membership count can be very quickly reflected in their stock prices, we focus on the change in the cost of equity between year $t-1$ and year $t+1$. To construct the group of treatment firms, we first identify all members of the eight SSOs before their closure. ${ }^{22}$ Firms in the treatment group are required to have non-missing cost of equity from year $t-1$ to year $t+1$ and non-missing matching variables in year $t-1$. Firms in the control group do not have a reduced SSO membership count due to the exogenous shock (because they were not members of the closing SSOs). For each treatment firm, we retain up to five closest control firms similar in terms of all variables in the baseline model (PATAPP, SIZE, VOLATILITY, MTB, LEVEAGE, ROA, $A G E$, FORECASTER and industry) in year $t-1$. We identify 185 unique pairs of treatment-control matches. ${ }^{23}$

Panel A of Table 5 reports the univariate comparisons between the treatment and control firms' key variables. All the differences are insignificant, implying that all the meaningful observable differences between the treatment and the control groups before the event have been successfully removed. Panel B reports the difference-in-differences (DiD) analysis results. We compute the DiD estimator by calculating, for each firm, the difference in the cost of equity in year $t+1$ relative to year $t-1$. The average cost of equity difference for the treatment and control groups is reported in columns (1) and (2), respectively. We note a much smaller average change in the cost of equity for the treatment $(-0.011)$ relative to that for the control $(-0.022)$ group. Column (3) reports the DiD estimator: the difference in the differences for the treatment and control groups is statistically significant at the $1 \%$ level (with the standard error clustered at the event level).

To check the sensitivity of our DiD analysis to the construction of the matched control group, we adjust our matching technique by including additional variables drawn from two strands of literature. First, following studies on the cost of equity (e.g., Lui et al., 2016), we match firms on R\&D intensity (RDI), SGAI (the ratio of sales and general administrative costs to sales), Financial slack (current assets over total assets), $K Z$ (financial constraints), as well as the performance indicators sales growth $(S G)$ and labour productivity (OIPE, operating income over employee count). Second, we treat standardization as a strategic choice and follow the business strategy literature (e.g., Lim et al., 2018) to match firms on capital intensity (CAP, the ratio of the net value of property, plant and equipment to total assets) and organizational stability (TEMP, the standard deviation in employment size). All additional data is collected from the Compustat-CRSP Merged Database. ${ }^{24}$ Matching on a larger set of variables reduces the sample to 170 matched pairs. The estimates in Panels C and D of Table 5 are very similar to those reported above (although treated firms appear to be slightly larger than control firms).

\footnotetext{
21 We utilize Wayback Machines to search the Internet archive for the official webpages of the SSOs before and after their closure to verify that each closure was finalized.

22 IEEE acquired I3A's CPIQ program and other assets in 2012. I3A disbanded in 2013. The new IEEE program has involved many of the corporate members that contributed to the original CPIQ program. As IEEE is included in our data, our treatment firms do not include those that became IEEE members after the merger and used to be I3A members before the merger.

${ }^{23}$ Using instead either 1-to-1 or 1-to-3 matching gives qualitatively similar results. Matching to fewer controls can help minimize bias at the cost of larger variance. Non-replacement keeps the variance low but at the cost of potential bias. Our algorithm imposes the common support restriction and a 0.0001 caliper.

${ }^{24}$ Additionally, we employ all these variables in a propensity score matching approach and report the results in the Online Appendix C.
}

Table 5

Difference-in-differences (DiD) test results.

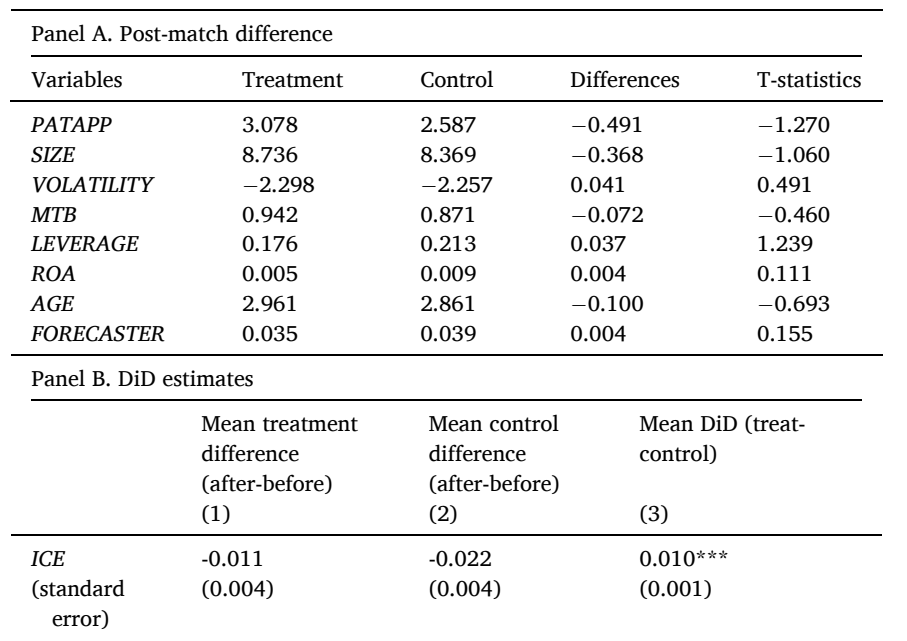

Robustness test on a different set of treatment-control matches

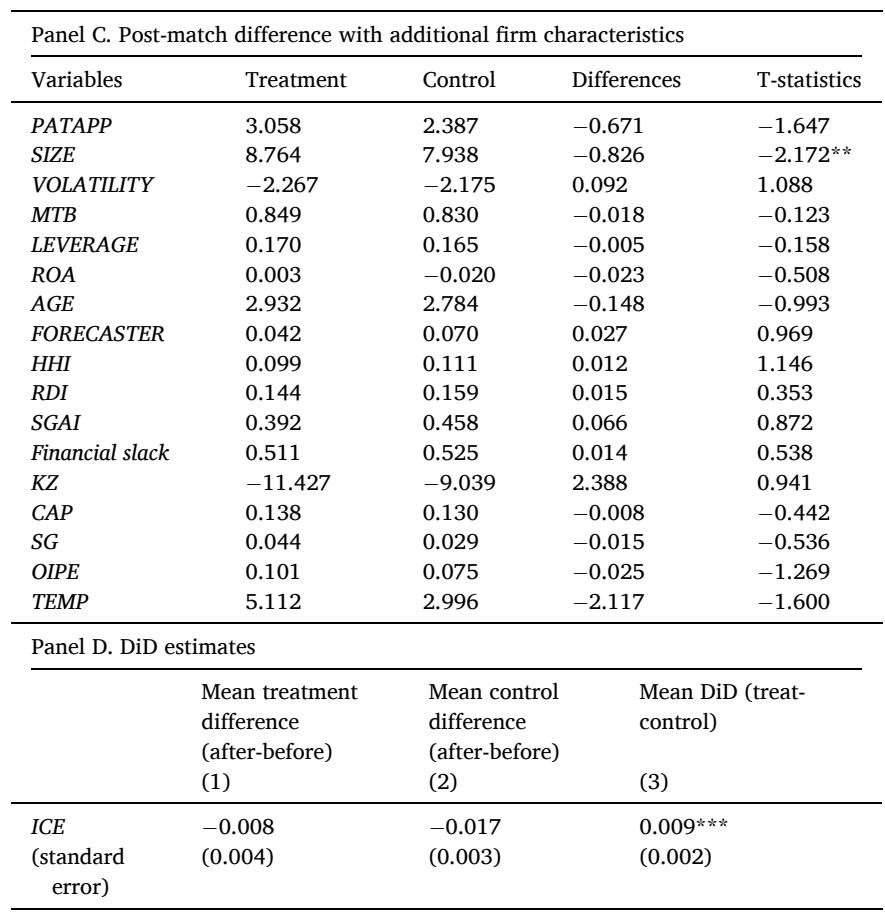

\section{Extended analysis}

In this section, we examine whether the capital markets' response to a firm's SSO participation is contingent on which SSOs it chooses to join and how patenting intensive the firm is.

\subsection{SSO heterogeneity}

The "forum shopping" literature has pointed to the important heterogeneity among SSOs and predicted that firms will choose between competing SSOs when seeking technological certification from them (Lerner and Tirole, 2006; Chiao et al., 2007). An important question thus remains as to whether financial market participants value differently a firm's association with more prestigious/influential SSOs. We employ network analysis to establish how influential an SSO is in facilitating knowledge exchange, promoting technology spillovers, and signalling quality (Lerner and Tirole, 2006). A network can be described as an $N^{*} N$ adjacency matrix, $A$, consisting of $N$ unique "nodes", which are 
connected through "edges". Each entry in $A$, denoted $a_{i j}$, records the strength of the connection between nodes $i$ and $j$. In our case, the "nodes" refer to SSOs connected via co-participating firms and the strength of the connection between two SSOs is the number of co-members. To illustrate these concepts, Fig. 2 presents representations of two simple SSO networks in our sample. The SCDB traces four SSOs in 1996; these have a total of 488 firm participation records. Panel A provides the symmetric adjacency matrix, where diagonal entries tally participants for each SSO and off-diagonal entries report co-participants with other SSOs. Panel B illustrates graphically the network, which consists of the four nodes

Panel A. Symmetric adjacency matrix example: SSOs in 1996

\begin{tabular}{r|cccc|} 
& ATSC & IMTC & UWCC & VESA \\
\cline { 2 - 5 } ATSC & 54 & 8 & 2 & 13 \\
IMTC & 8 & 139 & 10 & 24 \\
UWCC & 2 & 10 & 21 & 3 \\
VESA & 13 & 24 & 3 & 274 \\
\cline { 2 - 5 }
\end{tabular}
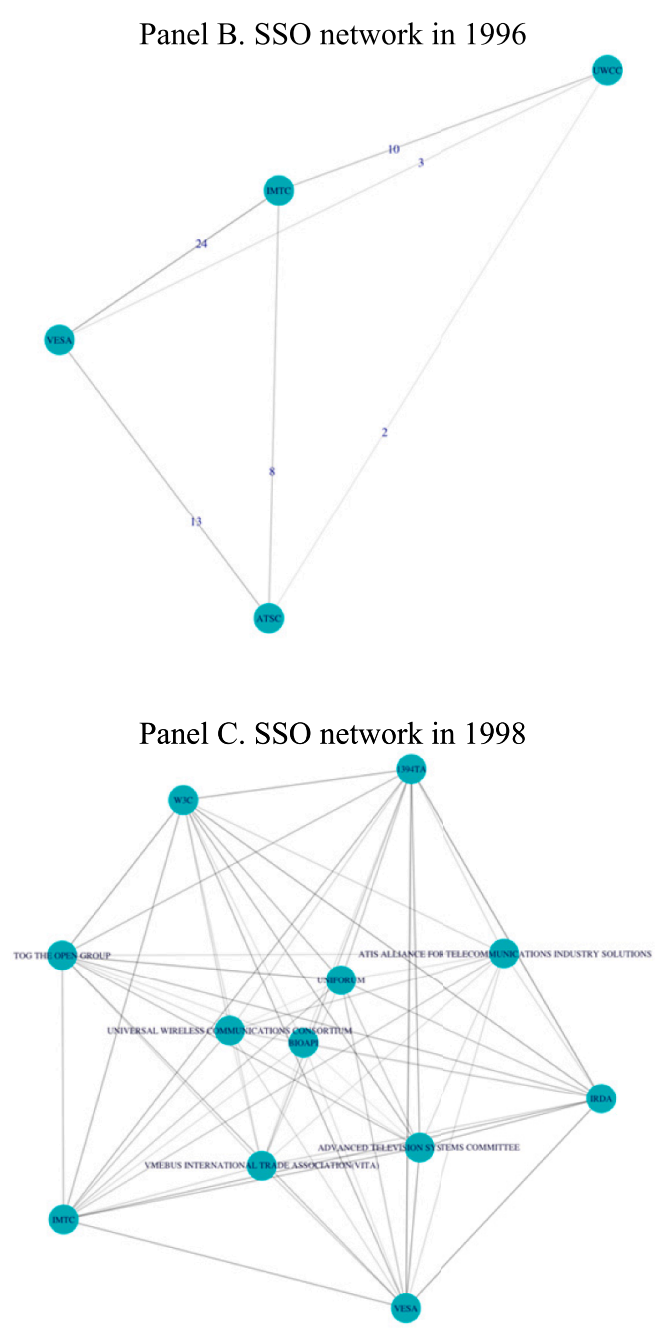

Fig. 2. Panel A is the symmetric adjacency matrix of the four recorded SSOs in 1996: Universal Wireless Communications Consortium (UWCC), Advanced Television Systems Committee (ATSC), the International Multimedia Telecommunications Consortium (IMTC) and Video Electronics Standards Association (VESA). Diagonal entries tally the number of participants, while off-diagonal entries represent the number of co-participants. Panel B plots the SSO network in 1996 shown in Panel A. The number/color shade of each edge refers to the weight attributes of the edge. Panel C plots the SSO network in 1998.
(SSOs) connected through undirected weighted edges. The attributes of the edges (color shade and number) reflect the number of co-participants. Panel C shows the increased complexity of the SSO network in 1998, when it had more SSOs and more firm participation.

To identify influential SSOs, we use the concept of network centrality, which captures the relative importance of a node or an edge in a graph. Following Ahern and Harford (2014), we utilize the eigenvector centrality measure proposed by Bonacich $(1987,2007)$. Specifically, for each SSO we calculate:

$\lambda x_{i t}=\sum_{j=1}^{n} a_{i j t} x_{j t}, i=1, \ldots, n$

where $x_{i t}$ is the eigenvector centrality of SSO $i$ in year $t, \lambda$ is the largest eigenvalue of the adjacency matrix and $n$ is the number of nodes. The eigenvector centrality is given by the principal eigenvector (corresponding to the largest eigenvalue of the symmetric matrix). ${ }^{25}$ Thus, each node's centrality is proportional to the sum of the centrality values of the other nodes it connects to. Intuitively, this measure considers the node to be more central if it is connected to other nodes that are central themselves. As such, the eigenvector measure captures the significance of an SSO's network position in terms of facilitating knowledge exchange and promoting technology spillovers through connecting firms that simultaneously participate in multiple SSOs. Membership of SSOs that enjoy a more influential position may thus be perceived to reduce a firm's cost of equity.

We follow this methodology to obtain the centrality measure of each SSO and label "influential" SSOs those with an above-median centrality value each year. We then use the new variables $I M E M B E R$ to indicate a firm's membership of influential SSOs and non-iMEMBER to indicate membership of non-influential SSOs. We also tally such influential SSO memberships and their non-influential counterparts (denoted as iMEMBERCOUNT and non-iMEMBERCOUNT, respectively). The estimates in Table 6 show that participation in (one or several) influential

Table 6

Extended analysis: SSO heterogeneity.

\begin{tabular}{lll}
\hline & $\begin{array}{l}\text { iMEMBER } \\
(1)\end{array}$ & $\begin{array}{l}\text { iMEMBERCOUNT } \\
(2)\end{array}$ \\
\hline iMEMBER & $-0.007^{* * *}$ & \\
non-iMEMBER & $(-2.840)$ & \\
& -0.004 & \\
iMEMBERCOUNT & $(-0.967)$ & $-0.012^{* * *}$ \\
non-iMEMBERCOUNT & & $(-5.067)$ \\
& & -0.008 \\
Controls & & $(-1.627)$ \\
Observations & YES & YES \\
$N$ of firms & 32,824 & 32,824 \\
R-squared & 3350 & 3350 \\
Industry FE & 0.276 & 0.276 \\
Year FE & YES & YES \\
Firm FE & YES & YES \\
\hline
\end{tabular}

This table presents the fixed effects estimates (t-statistics in parentheses). The dependent variable is the composite ICE measure. We use a network centrality measure to define firm membership in an influential SSO. iMEMBER is an indicator of firm participation in at least one influential SSO, while non-iMEMBER indicates participation only in non-influential SSOs. iMEMBERCOUNT records the number of influential memberships, while non-iMEMBERCOUNT records memberships only of non-influential SSOs. All firm-level characteristics are defined in Table 3. ${ }^{*} p<0.1 ; * * p<0.05 ;{ }^{* * *} p<0.01$.

\footnotetext{
25 For the SSO network in 1996, the eigenvector centrality measures are 0.983 for VESA, 0.173 for IMTC, 0.063 for ATSC, and 0.019 for UWCC.
} 
SSOs correlates negatively with the firm's cost of equity.

\subsection{Patenting activity}

We further investigate whether characteristics of a firm's patent portfolio interact with its membership status in determining its cost of equity capital. To this end, we utilize information on patenting intensity measured using patent applications and ownership of standard-essential patents (SEPs). We construct two dummies HPT (LPT) equal to 1 if the firm's number of patent applications is above (below) the industry-year median, and 0 otherwise. We identify SEP owners by mapping the largescale essential patents identified and used in Baron and Pohlmann (2018) to our dataset using company names. We then create SEP as a dummy variable equal to 1 if firm $i$ has at least one declared SEP in year $t$ - 1. We further distinguish between patent holders without SEPs (NoSEP) and non-patent holders (NoPT).

As shown in Table 7, our results indicate that the negative association between SSO participation and the implied cost of equity is statistically significant only among highly patent-intensive firms (column (1)) and is most marked among firms that own SEPs (column (2)). Put differently, the capital market values a firm's participation in standard development more if that firm owns a large number of patented technologies and especially if some of its patented technologies have been selected to be embedded in standards under development. These results resonate with prior studies that the inclusion of a patent within a standard significantly increases its value (Rysman and Simcoe, 2008) and that declared SEPs contribute to better firm performance than do comparable control assets (Pohlmann et al., 2015).

\section{Conclusion}

We report novel evidence on the effect of SSO membership on a firm's cost of equity capital. The implied cost of equity reflects the rate of return investors require, and so represents a crucial input to long-term investment decisions (Boubaker et al., 2018). Understanding of how engagement with standard setting affects investors' perceptions of a firm's riskiness has far-reaching implications for corporate strategic and financial planning.

Against the backdrop of rapid technology development in recent

Table 7

Extended analysis: patenting activity.

\begin{tabular}{lll}
\hline & $\begin{array}{l}\text { Patent applications } \\
(1)\end{array}$ & $\begin{array}{l}\text { SEP holding } \\
(2)\end{array}$ \\
\hline MEMBER \# HPT & $-0.009^{* * *}$ & \\
& $(-3.240)$ & \\
MEMBER \# LPT & -0.004 & \\
& $(-1.383)$ & $-0.016^{* *}$ \\
MEMBER \# SEP & & $(-2.387)$ \\
MEMBER \# NoSEP & & -0.005 \\
& & $(-1.395)$ \\
MEMBER \# NoPT & & -0.004 \\
& & $(-1.227)$ \\
Controls & YES & YES \\
Observations & 32,824 & 32,824 \\
$N$ of firms & 3350 & 3350 \\
R-squared & 0.276 & 0.276 \\
Industry FE & YES & YES \\
Year FE & YES & YES \\
Firm FE & YES & YES
\end{tabular}

This table presents the fixed effects estimated coefficients (t-statistics in parentheses). The dependent variable is the composite ICE measure. High (Low) HPT takes the value 1 if the firm's number of patent applications is above (below) the industry-year median, and 0 otherwise. SEP takes the value 1 if the firm holds at least one standard-essential patent (SEP), and 0 otherwise. The non-SEP holders are separated into patent (NoSEP) and no-patent holders (NoPT). All firm-level characteristics are defined in Table $3 . * p<0.1 ; * * p<0.05 ; * * * p<0.01$. years, firms strategically manage conflicting pressures to develop open standards collaboratively or to create competitive distinction in developing innovative products or services. Our research thus throws light on the trade-off between these pressures (see Waguespack and Fleming, 2009; Gnyawali and Park, 2011; Chiambaretto et al., 2019; Jones et al., 2020). Given the goals and potential pitfalls of participating in SSOs, this study offers a timely evaluation of whether the benefits of SSO membership outweigh its costs through the eyes of investors.

The analysis of 3350 US public firms and their memberships of 183 SSOs from 1996 to 2014 shows a significantly lower cost of equity for SSO participants. This finding resonates with evidence documented by Aggarwal et al. (2011) in their study of the nexus between financial risks and IT standard-setting initiatives. Using an event-study approach, those authors show that a larger standardization group decreases the risk-adjusted abnormal return and the market risk of individual firms (i. e., beta) while increasing their idiosyncratic risk (i.e., variance of returns). Our results further document that this negative correlation between SSO membership and the implied cost of equity is most pronounced when a firm joins an SSO for the first time.

Our analysis takes into account the endogenous nature of a firm's decision to participate in standard development. In particular, a firm's propensity to join one or multiple SSOs may be related to unobservable time-varying effects on its cost of equity, and thus our estimated impact of SSO membership may suffer from selection bias in the absence of random assignment (i.e., SSO member firms do not constitute a randomly selected group). Reverse causality may also arise, as firms with a lower cost of equity are better financially equipped to participate in SSOs. However, our main finding of the negative relationship between SSO membership and the implied cost of equity is robust to an instrumental variable model and a difference-in-differences approach. In particular, our quasi-natural experiment based on SSO closures utilizes an exogenous variation in membership count to identify the impact of membership. This identification strategy postulates that such variation in the supply of SSOs is not driven by the demand of individual firms stemming from their standardization strategies; if such an assumption were to hold, this part of our analysis should have a causal interpretation.

Our study sheds light on how participation in SSOs might attenuate the risk perceived by investors. Utilizing various empirical measures to unpack the risks arising from technology and market sources, we find that SSO members facing higher levels of technological and/or productmarket uncertainty have particularly benefited from a discounted cost of equity. Technical standards encompass an industry's technological base and provide a non-proprietary and critical infrastructure upon which more advanced and complex innovation can be developed (Foucart and Li, 2021). SSO members can directly influence, contribute to, and learn from standards collectively developed with other members, all of which will likely lower the technological uncertainty involved in their own innovation. At the same time, firms in competitive product markets encounter a higher level of uncertainty. Timely standard development can accelerate firms' product innovation and diversification into new product markets (David and Steinmueller, 1994; Soh, 2010; Blind and Mangelsdorf, 2016); it can reduce market uncertainty deriving from competition and customer-base shocks (Blind et al., 2017). Lastly, we find that SSO members benefit from a reduced cost of equity if they suffer a higher level of information asymmetry in the capital markets (i. e., being more financially constrained, receiving less analyst coverage, and facing more illiquidity in the stock markets). These results suggest that SSO membership sends a positive signal and provides important information to the financial markets regarding a firm's technical and strategic development, which can alleviate investment risks emanating from asymmetric information between firms and investors.

Lastly, in our extended analyzes, our results highlight that membership of more influential/central SSOs is associated with a greater reduction in the cost of equity than is the case for membership of peripheral SSOs, which resonate with the "forum shopping" literature 
(Lerner and Tirole, 2006). We also find evidence that patenting intensity and ownership of SEPs significantly influences the capital markets' response to a firm's SSO participation. This is reminiscent of the different benefits of SSO membership accruing to technology developers (firms that frequently make technological contributions to standards) versus technology implementers (firms that utilize developed standards to bring to market standard-compliant products or services). Our empirical findings are in line with observations in prior works that SSOs are able to cherry-pick promising technologies from technology developers. The subsequent endorsement of such technologies by SSOs can significantly accelerate their adoption thus adding considerable value to sponsored technologies and to the owner firms (Rysman and Simcoe, 2008).

Our study has several caveats. As we drew membership information from the SCDB, our empirical measures of SSO participation are subject to a trade-off between the precision or depth of coverage and the need to incorporate SSO-, technology- and firm-level heterogeneity to better understand the wider impact of technology standardization. Prior studies of a single SSO have utilized various proxies to capture the degree of participation and effort employed by participants. For instance, Leiponen (2008) and Baron and Gupta (2018) exploit detailed written contributions made by firms to the development of new technical specifications within 3GPP committees. Waguespack and Fleming (2009) consider four indicators of firms' engagement in the Internet Engineering Task Force (IETF): gaining endorsement of their own standards, developing their own technology, meeting attendance, and taking leadership positions. However, such detailed participation records are available from only a handful of SSOs, which makes comparison and generalization across a representative sample of SSOs impractical.

Our analysis derives insight from listed firms. It would be interesting to assess whether the cost of capital of small and unlisted firms, arguably affected by higher information asymmetry, is also affected by their engagement with technology standardization. Our unique setting allows a comprehensive assessment of the financial market impact of SSO membership and accounts for a firm's choice as to which and how many SSOs to join. One fruitful avenue for future research thus lies in the use of more detailed contribution data or membership tier information for both private and listed firms to capture SSO participation more precisely.

\section{CRediT authorship contribution statement}

Xin Deng: Conceptualization, Resources, Data curation, Formal analysis, Methodology, Writing, Editing. Qian Cher Li: Conceptualization, Writing, Editing, Resources, Methodology, Supervision. Simona Mateut: Conceptualization, Writing, Editing, Methodology, Supervision.

\section{Declaration of Competing Interest}

The authors declare that they have no known competing financial interests or personal relationships that could have appeared to influence the work reported in this paper.

\section{Acknowledgments}

We would like to thank Shamim Ahmed, Kevin Amess, Geert Boedt, Thanaset Chevapatrakul, Renaud Foucart, Joachim Henkel, Lina Song, Mo Tian, Piercarlo Zanchettin, the editor Alex Coad, associate editor Aija Leiponen, and two anonymous referees for their helpful comments which have greatly improved this research. We are also grateful for feedback received from participants at the 2021 European Policy for Intellectual Property Conference, the 2021 Congress of the European Accounting Association, the 2021 ESCoE Conference on Economic Measurement, the 2020 Summer School on Data and Algorithms for Science, Technology \& Innovation Studies, and seminar audience at Nottingham University Business School in 2019. Cher Li is grateful for the support by the Economic and Social Research Council [ESRC grant ref. ES/T001771/1].

\section{Supplementary materials}

Supplementary material associated with this article can be found, in the online version, at doi:10.1016/j.respol.2022.104497.

\section{Appendix}

Measurement of the cost of equity

Our cost of equity measure (ICE) is calculated as the equal-weighted average of the estimates from four models. Formally, ICE $=$ average $\left(R_{g l s}+\right.$ $R_{c t}+R_{o j}+R_{e s}$ ), where $R_{g l s}, R_{c t}, R_{o j}, R_{e s}$ are the cost of equity estimates obtained from the models of Gebhardt et al. (2001), Claus and Thomas (2001), Easton (2004), and Ohlson and Juettner-Nauroth (2005), respectively. To address the issues regarding analysts' forecasts discussed in Section 3.2, we use the forecasting procedure developed by Hou et al. (2012) (HVZ model) to obtain earnings forecasts.

We present in detail the four methods used to obtain the cost of equity and the HVZ forecasting model. To maximize coverage, we require a firm to have at least one non-missing value of ICE estimates computed from the four models.

The four models for estimating the cost of equity

Model 1: $\boldsymbol{R}_{\text {gls }}$ - Gebhardt et al. (2001). The cost of equity is estimated from the following residual income valuation model:

$P_{t}=B_{t}+\sum_{\tau=1}^{\tau=11} \frac{\left(F R O E_{t+\tau}-R_{g l s}\right) * B_{t+\tau-1}}{\left(1+R_{g l s}\right)^{t+\tau}}+\frac{\left(F R O E_{t+12}-R_{g l s}\right) * B_{t+11}}{R_{g l s}\left(1+R_{g l s}\right)^{t+12}}$,

where

- $P_{t}=$ the end-of-June stock price for year $t$.

- $B_{t+\tau}=$ the book value per share for the estimation year, the clean surplus is applied where $B_{t+\tau}=B_{t+\tau-1}+F E P S_{t+\tau}-D P S_{t+\tau}$.

- $F R O E_{t+\tau}=$ the earnings forecasts derived from the HVZ model (explained in the following) divided by book value in year $t+\tau-1$.

- $F E P S_{t+\tau}=F R O E_{t+\tau} * B_{t+\tau-1}$. 
- $D P S_{t+\tau}=$ the dividend pay-out per share in year $t+\tau$.

Following Gebhardt et al. (2001) and Claus and Thomas (2001), the current pay-out ratio is measured as dividends divided by income before extraordinary items for firms with positive current earnings or dividends divided by $6 \%$ of total assets for firms with negative income before extraordinary items; missing values are then replaced with $50 \%$.

The estimation of $R_{g l s}$ is based on a 12-year period. The linear interpolation is applied to let the five-year-ahead $F R O E_{t+\tau}$ fade to the industry ROE median in year 12, while the industry ROE median is obtained from all ROEs within the same industry over the past 5 years and up to 10 years. The industry classification is based on the Fama-French 48 industry classification (Fama and French, 1997). We use a numerical approximation program to solve for $R_{g l s}$ within 0 and $100 \%$, allowing for the right- and left-hand sides within a difference of $\$ 0.001$.

Model 2: $\boldsymbol{R}_{\boldsymbol{c} t}$ - Claus and Thomas (2001). Claus and Thomas (2001) calculate the cost of equity using the following model:

$P_{t}=B_{t}+\sum_{\tau=1}^{\tau=5} \frac{\left(F R O E_{t+\tau}-R_{c t}\right)^{*} B_{t+\tau-1}}{\left(1+R_{c t}\right)^{t+\tau}}+\frac{\left(F R O E_{t+5}-R_{c t}\right)(1+g)^{*} B_{t+4}}{\left(R_{c t}-g\right)\left(1+R_{c t}\right)^{t+5}}$

where

- $P_{t}=$ the end-of-June stock price for year $t$.

- $B_{t+\tau}=$ the book value per share for the estimation year.

- $F R O E_{t+\tau}=$ the earnings forecasts derived from the HVZ model (explained below) divided by book value in year $t+\tau-1$.

- $g=$ the long-term rate equal to the contemporaneous risk-free rate in June (the yield on 10-year Treasury bonds) minus $3 \%$.

We use a numerical approximation program to solve for $R_{c t}$ within 0 and $100 \%$, allowing for the right- and left-hand sides within a difference of $\$ 0.001$. We set the long-term growth rate as the upper bound of the equation.

Model 3: $\boldsymbol{R}_{\boldsymbol{o j}}$ - Ohlson and Juettner-Nauroth (2005). The third measure is based on an abnormal earnings growth valuation model from Ohlson and Juettner-Nauroth (2005) and modified by Gode and Mohanram (2003):

$R_{o j}=A+\sqrt{A^{2}+\frac{F E P S_{t+1}}{P_{t}}\left(g_{2}-(\gamma-1)\right)}$,

where

- $\mathrm{A}=\frac{1}{2}\left((\gamma-1)+\frac{D P S_{t+1}}{p_{t}}\right)$ while $(\gamma-1)$ is the contemporaneous risk-free rate minus $3 \%$.

- $g_{2}=0.5^{*}\left(\frac{E_{3}-E_{2}}{E_{2}}+\frac{E_{5}-E_{4}}{E_{4}}\right)$ where $E_{n}(n=1,2, \cdots, 5)$ is the earnings forecasts from the HVZ model.

- FEPS $_{t+\tau}=F R O E_{t+\tau} * B_{t+\tau-1}$.

We require $R_{o j}$ within 0 and $100 \%$. The model also requires a positive change in forecasted earnings to yield a numerical solution.

Model 4: $\boldsymbol{R}_{\boldsymbol{e s}}$ - Easton (2004). We finally estimate the cost of equity based on the modified price-earnings growth model in Easton (2004). We calculate the cost of equity by the following model:

$P_{t}=\frac{F E P S_{t+1}+D P S_{t+1} * R_{e s}-F E P S_{t+1}}{R_{e s}{ }^{2}}$,

where

- $P_{t}=$ the end-of-June stock price for the estimation year.

- FEPS $_{t+\tau}=F R O E_{t+\tau}{ }^{*} B_{t+\tau-1}$.

- $D P S_{t+\tau}=$ the dividend pay-out per share in year $t+\tau$.

Following Gebhardt et al. (2001) and Claus and Thomas (2001), the current pay-out ratio is measured as dividends divided by income before extraordinary items for firms with positive current earnings or dividends divided by $6 \%$ of total assets for firms with negative income before extraordinary items; missing values are then replaced with $50 \%$.

We use a numerical approximation program to solve for $R_{e s}$ within 0 and $100 \%$, allowing for the right- and left-hand sides within a difference of $\$ 0.001$. Note that the model requires positive change in forecasted earnings to yield a numerical solution.

The HVZ forecasting procedure. We employ the forecasting procedure developed by Hou et al. (2012) to estimate earnings for year $t+1$ to year $t+5$. Specifically, we estimate the following pooled cross-sectional regression by using the past 10 years of data to generate the earnings forecasts. The earnings and other level variables are winsorized each year at $1^{\text {st }}$ and $99^{\text {th }}$ percentiles. To keep the survivorship bias to a minimum, only firms with non-missing values for independent variables in year $t$ are included in estimation.

$E_{i, t+\tau}=\alpha_{0}+\alpha_{1}{ }^{*} A_{i, t}+\alpha_{2}{ }^{*} D_{i, t}+\alpha_{3} * D D_{i, t}+\alpha_{4}{ }^{*} E_{i, t}+\alpha_{5}{ }^{*} N e g E_{i, t}+\alpha_{6}{ }^{*} A C_{i, t}+\varepsilon_{i, t+\tau}$, 
where

- $E_{t+\tau}=$ income before extraordinary items in year $t+\tau$.

- $A_{i, t}=$ total assets in year $t$.

- $D_{i, t}=$ dividend payment in year $t$.

- $D D_{i, t}=$ dummy variable taking the value 1 for dividend payers, 0 otherwise.

- $N e g E_{i, t}=$ dummy variable equal to 1 if firms have negative earnings, 0 otherwise.

- $A C_{i, t}=$ accruals.

All explanatory variables are measured as of year $t$. Following Hou et al. (2012), we use the financial data of firms with fiscal-year end from April of year $t-1$ to March of year $t$ in the estimation for year $t$ to reduce look-ahead bias.

\section{References}

Acharya, V., Xu, Z., 2017. Financial dependence and innovation: The case of public versus private firms. J. Financ. Econ. 124 (2), 223-243.

Adams, R., Almeida, H., Ferreira, D., 2009. Understanding the relationship between founder-CEOs and firm performance. J. Empir. Financ. 16 (1), 136-150.

Aggarwal, N., Dai, Q., Walden, E.A., 2011. The more, the merrier? How the number of partners in a standard-setting initiative affects shareholder's risk and return. MIS Q. 445-462.

Ahern, K.R., Harford, J., 2014. The importance of industry links in merger waves. J. Financ. 69 (2), 527-576.

Amihud, Y., 2002. Illiquidity and stock returns: cross-section and time-series effects. J. Financ. Mark. 5 (1), 31-56.

Angrist, J.D., Pischke, J.S., 2008. Mostly Harmless Econometrics: An Empiricist's Companion. Princeton university press, pp. 142-145.

Baron, J., Gupta, K., 2018. Unpacking 3GPP standards. J. Econ. Manag. Strategy 27 (3), 433-461.

Baron, J., Li, Q.C., Nasirov, S., 2019. Why do R\&D-intensive firms participate in standards organizations? The role of patents and product-market position. SSRN Electron. J. Available at https://ssrn.com/abstract $=3287475$.

Baron, J., Pohlmann, T., 2018. Mapping standards to patents using declarations of standard-essential patents. J. Econ. Manag. Strategy 27 (3), 504-534.

Baron, J., Spulber, D.F., 2018. Technology standards and standard setting organizations: introduction to the searle center database. J. Econ. Manag. Strategy 27 (3), 462-503.

Belenzon, S., Patacconi, A., 2013. Innovation and firm value: an investigation of the changing role of patents, 1985-2007. Research Policy 42 (8), 1496-1510.

Besen, S.M., Farrell, J., 1994. Choosing how to compete: strategies and tactics in standardization. J. Econ. Perspect. 8 (2), 117-131.

Blind, K., Mangelsdorf, A., 2016. Motives to standardize: empirical evidence from Germany. Technovation 48, 13-24.

Blind, K., Petersen, S.S., Riillo, C.A.F., 2017. The impact of standards and regulation on innovation in uncertain markets. Res. Policy 46 (1), 249-264.

Bonacich, P., 1987. Power and centrality: a family of measures. Am. J. Sociol. 92 (5), $1170-1182$.

Bonacich, P., 2007. Some unique properties of eigenvector centrality. Social networks 29 (4), 555-564.

Boubaker, S., Boubakri, N., Grira, J., Guizani, A., 2018. Sovereign wealth funds and equity pricing: evidence from implied cost of equity of publicly traded targets. J. Corp. Financ. 53, 202-224.

Boubakri, N., Guedhami, O., Mishra, D., Saffar, W., 2012. Political connections and the cost of equity capital. J. Corp. Financ. 18 (3), 541-559.

Brown, J.R., Fazzari, S.M., Petersen, B.C., 2009. Financing innovation and growth: cash flow, external equity, and the 1990s R\&D boom. J. Financ. 64 (1), 151-185.

Chen, T., Lin, C., 2017. Does information asymmetry affect corporate tax aggressiveness? J. Financ. Quant. Anal. 52 (5), 2053-2081.

Chen, Z., Li, O.Z., Zou, H., 2016. Directors' and officers' liability insurance and the cost of equity. J. Account. Econ. 61 (1), 100-120.

Chiambaretto, P., Bengtsson, M., Fernandez, A.S., Näsholm, M.H., 2019. Small and large firms' trade-off between benefits and risks when choosing a coopetitor for innovation. Long Range Plan. 53 (1), 101876.

Chiao, B., Lerner, J., Tirole, J., 2007. The rules of standard-setting organizations: an empirical analysis. Rand J. Econ. 38 (4), 905-930.

Claus, J., Thomas, J., 2001. Equity premia as low as three percent? Evidence from analysts' earnings forecasts for domestic and international stock markets. J. Financ 56 (5), 1629-1666.

Czarnitzki, D., Toole, A.A., 2011. Patent protection, market uncertainty, and R\&D investment. Rev. Econ. Stat. 93 (1), 147-159.

David, P.A., Steinmueller, W.E., 1994. Economics of compatibility standards and competition in telecommunication networks. Inf. Econ. Policy 6 (3-4), 0-241.

Delcamp, H., Leiponen, A., 2014. Innovating standards through informal consortia: the case of wireless telecommunications. Int. J. Ind. Organ. 36, 36-47.

Dhaliwal, D., Judd, J.S., Serfling, M., Shaikh, S., 2016. Customer concentration risk and the cost of equity capital. J. Account. Econ. 61 (1), 23-48.

Easton, P., 2004. PE ratios, PEG ratios, and estimating the implied expected rate of return on equity capital. Account. Rev. 79, 73-95.

Fama, E.F., French, K.R., 1997. Industry costs of equity. J. Financ. Econ. 43, 152-194.

Fama, E.F., French, K.R., 2000. Forecasting profitability and earnings. J. Bus. 73, $161-175$
Fama, E.F., French, K.R., 2006. Profitability, investment and average returns. J. Financ. Econ. 82, 491-518.

Fu, R., Kraft, A., Zhang, H., 2012. Financial reporting frequency, information asymmetry, and the cost of equity. J. Account. Econ. 54 (2-3), 132-149.

Foucart, R., Li, Q.C., 2021. The role of technology standards in product innovation: theory and evidence from UK manufacturing firms. Res. Policy 50 (2), 104157.

Garcia-Vega, M., Kneller, R., Stiebale, J., 2021. Labor market reform and innovation: evidence from Spain. Res. Policy 50 (5), 104213.

Gebhardt, W., Lee, C., Swaminathan, B., 2001. Toward an implied cost of capital. J. Account. Res. 39, 135-176.

Gnyawali, D.R., Park, B.J., 2011. Co-opetition between giants: collaboration with competitors for technological innovation. Res. Policy 40 (5), 650-663.

Gode, D., Mohanram, P., 2003. Inferring the cost of capital using the Ohlson-Juettner model. Rev. Account. Stud. 8 (4), 399-431.

Griliches, Z., 1990. Patent statistics as economic indicators: a survey. J. Econ. Lit. 28 (4), 1617-1661.

Guo, B., Pérez-Castrillo, D., Toldrà-Simats, A., 2019. Firms' innovation strategy under the shadow of analyst coverage. J. Financ. Econ. 131 (2), 456-483.

Hall, B.H., Jaffe, A., Trajtenberg, M., 2005. Market value and patent citations. Rand J. Econ. 16-38.

Hall, B.H., 2010. The financing of innovative firms. Rev. Econ. Inst. 1 (1).

Hail, L., Leuz, C., 2009. Cost of capital effects and changes in growth expectations around US cross-listings. J. Financ. Econ. 93 (3), 428-454.

Hong, H., Lim, T., Stein, J.C., 2000. Bad news travels slowly: size, analyst coverage, and the profitability of momentum strategies. J. Financ. 55 (1), 265-295.

Hou, K., Van Dijk, M.A., Zhang, Y., 2012. The implied cost of capital: a new approach. J. Account. Econ. 53 (3), 504-526.

Hou, K., Robinson, D.T., 2006. Industry concentration and average stock returns. J. Financ. 61 (4), 1927-1956.

Hussinger, K., Pacher, S., 2019. Information ambiguity, patents and the market value of innovative assets. Res. Policy 48 (3), 665-675.

Jalonen, H., 2012. The uncertainty of innovation: a systematic review of the literature. J. Manag. Res. 4 (1), 1.

Jones, S.L., Leiponen, A., Vasudeva, G., 2020. The evolution of cooperation in the face of conflict: evidence from the innovation ecosystem for mobile telecom standards development. Forthcoming in Strateg. Manag. J. 42 (4), 710-740.

Kaplan, S.N., Zingales, L., 1997. Do investment-cash flow sensitivities provide useful measures of financing constraints? Q. J. Econ. 112 (1), 169-215.

Katz, M.L., Shapiro, C., 1994. Systems competition and network effects. J. Econ. Perspect. 8 (2), 93-115.

Kogan, L., Papanikolaou, D., Seru, A., Stoffman, N., 2017. Technological innovation, resource allocation, and growth. Q. J. Econ. 132 (2), 665-712.

Leiponen, A.E., 2008. Competing through cooperation: the organization of standard setting in wireless telecommunications. Manag. Sci. 54 (11), 1904-1919.

Lerner, J., Tirole, J., 2006. A model of forum shopping. Am. Econ. Rev. 96 (4), 1091-1113.

Lim, E.K., Chalmers, K., Hanlon, D., 2018. The influence of business strategy on annual report readability. J. Account. Public Policy 37 (1), 65-81.

Lui, A.K., Ngai, E.W., Lo, C.K., 2016. Disruptive information technology innovations and the cost of equity capital: the moderating effect of CEO incentives and institutional pressures. Inf. Manag. 53 (3), 345-354.

Ohlson, J.A., Juettner-Nauroth, B.E., 2005. Expected EPS and EPS growth as determinants of value. Rev. Account. Stud. 10 (2-3), 349-365.

Ortiz-Molina, H., Phillips, G.M., 2014. Real asset illiquidity and the cost of capital. J. Financ. Quant. Anal. 49 (1), 1-32.

Pham, A., 2019. Political risk and cost of equity: the mediating role of political connections. J. Corp. Financ. 56, 64-87.

Pohlmann, T., Neuhäusler, P., Blind, K., 2015. Standard essential patents to boost financial returns. R\&D Manag. 46 (S2), 612-630.

Rysman, M., Simcoe, T., 2008. Patents and the performance of voluntary standard-setting organizations. Manag. Sci. 54 (11), 1920-1934.

Simcoe, T., 2012. Standard setting committees: consensus governance for shared technology platforms. Am. Econ. Rev. 102 (1), 305-336.

Simcoe, T., Graham, S., Feldman, M., 2009. Competing on standards? Entrepreneurship, intellectual property, and platform technologies. J. Econ. Manag. Strategy 18 (3), $775-816$.

Shleifer, A., Vishny, R.W., 2003. Stock market driven acquisitions. J. Financ. Econ. 70 (3), 295-311. 
Soh, P.H., 2010. Network patterns and competitive advantage before the emergence of a dominant design. Strategic Manag. J. 31, 438-461.

Tassey, G., 2000. Standardization in technology-based markets. Res. Policy 29 (4-5), 587-602.
Updegrove, A., 2006. Participating in standard setting organizations: value propositions, roles and strategies. Consort. Stand. Bull. 5 (9). https://www.consortiuminfo.org/gu roles and strategies. Consort. Stand. Bull. 5 (9). https://www.conso
ide/participating-in-a-sso/value-propositions-roles-and-strategies/.

Waguespack, D.M., Fleming, L., 2009. Scanning the commons? Evidence on the benefits to startups participating in open standards development. Manag. Sci. 55 (2), $210-223$. 